Portland State University

PDXScholar

$5-1-1970$

\title{
A study of the effects of professional authority on the attitude change of high school sophomores
}

\author{
Sandra Lee Kelley \\ Portland State University \\ Lane Alan Myers
}

Follow this and additional works at: https://pdxscholar.library.pdx.edu/open_access_etds

\section{Let us know how access to this document benefits you.}

\section{Recommended Citation}

Kelley, Sandra Lee and Myers, Lane Alan, "A study of the effects of professional authority on the attitude change of high school sophomores" (1970). Dissertations and Theses. Paper 668.

https://doi.org/10.15760/etd.668

This Thesis is brought to you for free and open access. It has been accepted for inclusion in Dissertations and Theses by an authorized administrator of PDXScholar. Please contact us if we can make this document more accessible: pdxscholar@pdx.edu. 
AN ABSTRACS OF MHE TH, TS of Sandra loe kedley and

Iane Alan Myors for tie Mascer of Socka work presented May 32,1970

Title: A study of the Effects of frofessional Authotity on the Attitude Change of High School Sophomores.

APRROVED BY MEMRERS OF MIE THESTS COMTTREE:
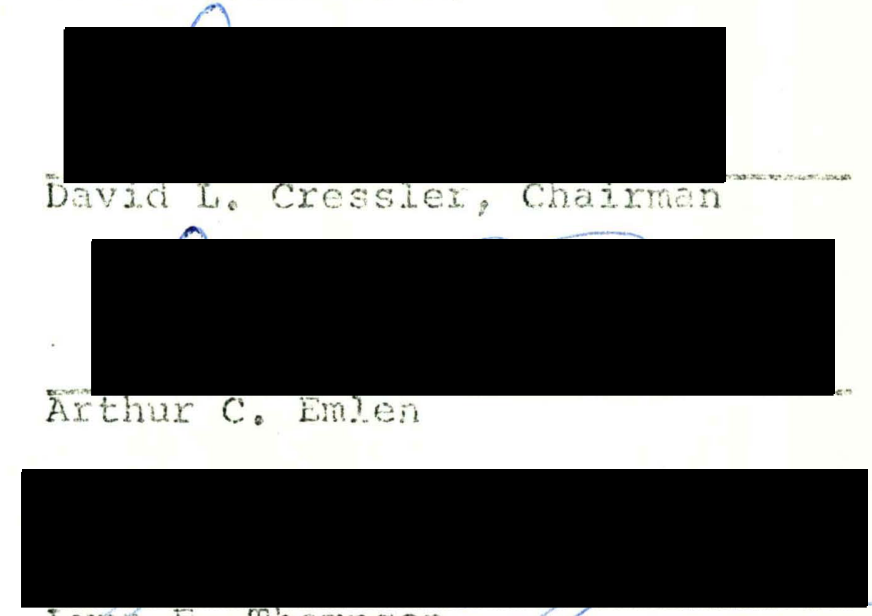

Lym E. Thompson

This reseaxch project was designed to test, directiy, the effects of perceived professional authority on producing attitude change anong high school sophomores. The study ut... jaed a social perchological theoretical orientation to exande a specific aspect of socially mediated information, ramely, persuastve commuication as it is influenced by the source or commulcator of the persuasive message. "Authority," as it has been defined in this study includes two factors: (1) the prestice and (2) the credihinty of the source. The two prom 
fessions selected were that of a physician and a social worker. It was expected that the physician, by virtue of his "higher perceived authority," as evidenced by previous research would be more effective in producing attitude change than would the social worker.

Data was obtained by means of a modified version of the traditional pretest-posttest with control group design. Alcohol usage and abusage was selected as the topic of the persuasive communication. The dependent variable selected for study was the students' attitudes toward alcohol usage, as measured by the scores they received on an attitude instrum ment. The independent variable was the perceived authority of the source or communicator.

The experiment utilized 140 students randomly selected from a total population of approximately 600 sophomore students. The 140 students were matched by triplets into six different experimental conditions from the scores each student received on an alcohol knowledge questionnaire. The ex periment was conducted on two different days. On the first day, the students received the alcohol knowledge questionnaire; on the second day, the pretest, stimulus, and post.est were administered. A single actor, assuming both the physician and the social worker roles, delivered an identical message concerning the detrimental physical and psychological effects of alcohol usage. Statistical analyses utilized an analysis of covariance. 
The results showed that the experimental manipulation of perceived authority had no significant effect upon the stum dents' attitudes toward the use and abuse of alcohol. In other words, the physician failed to be more successful in producing attitude change than the social worker.

Implications for the field of social work are mainly speculative, Social work directly involves the process of communication. However, the social work profession has infre quently dealt directly with the issue of influence (persuasion as it is related to attitude change. The question of authority as it relates to the effectiveness of the social worker still remains unanswered. 
A STUDY OE THE LEFECTS OE PROFESSTONAL AUTHORITY ON THE ATTTTUDE CHANGE OP HTGH SCHOOL SOPHOMORES

\section{by}

SANDRA IEE KEISEY

IANE ALAN MYERS

A thesis submitted in partial fulfildnent of the requixements for the degree of

MASTER OF SOCIAI WORK

Portland State Univorsity

1970 
TO THE OEFICE OE GRADUATE STUDTES:

The members of the Committee approve the thesis of Sandra Lee Kelley and Lane Alan Myers presented May 12, 1970.
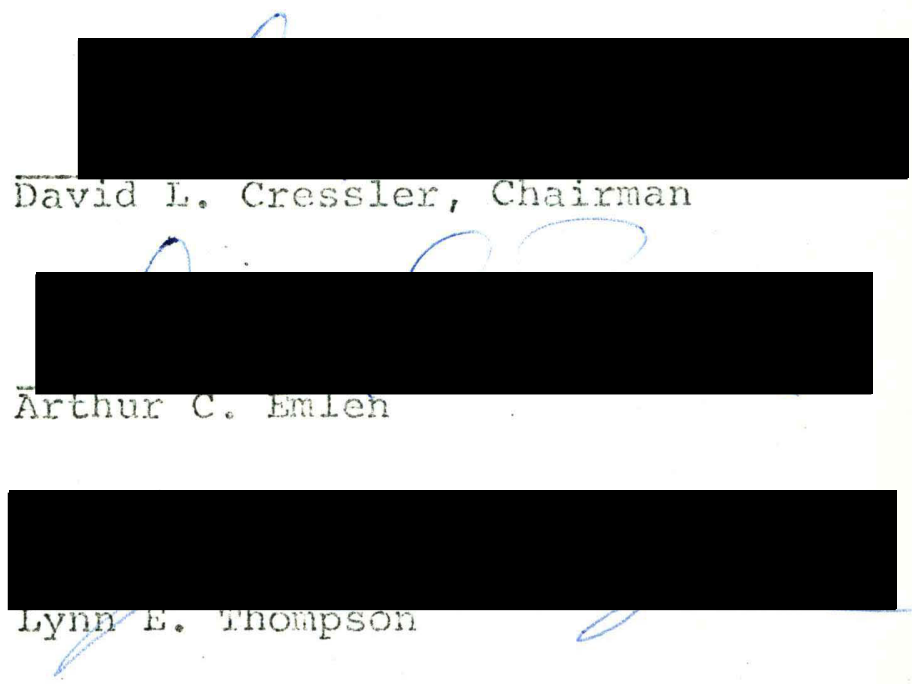

APPROVED :

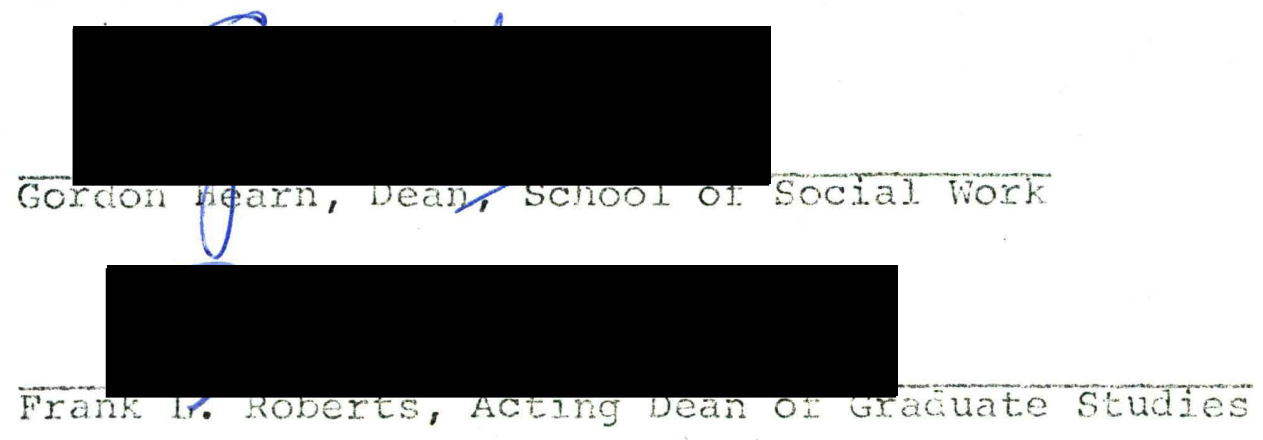

May 14, 2970 


\section{ACKNOWLEDGYENTS}

This study was done with the aid and supervision of thesis chaiman, Mr. David L. Cressier, M.A., and thesis committee members, Dr. Arthur C. Fmlen, M.S.W., PhD., and Mr. Lynn E. Thompson, M.S.W.

We are greatly indebted to the Salem Public School Board and Mr. Edmund E. Carlton, Principal of Noxth Salem High School, Salem, oregon, for their helpful cooperation; and to Mr. Bergex, Mr. Buckley, and Mr. Gover, teachers, for their indispensible assistance in carrying out the experiment. We would like to acknowledge Rev. Charles Farnham, Director of: Ministerial Services, Fairview Hospital and Training Center, Salem, Oregon, for his participation in the experiment. We would also like to express our appreciation to Sharyn McDonald, who was responsible for the typing of this thesis.

We would like to thank the Alabama Division of Alcoholism,* Alabama Department of Mental Health, for the use of their two booklets: Techniques for the Assessment of selected Attitudes Toward Alcohol and Its Use, and Development of a Scale for the Assessment of Knowledge Concerning Alcohol and Its Use. We would also like to thank the State Department of Education and the Oregon Alcohol Education Committee 
for the use of theix manual, Alcohol Education in oregon Public Schools. 
PAGE

ACKNOWLEGRENTS . . . . . . . . . . . . iii LIST OF TABLES ................ v vili LIST OF FIGURES ................ ix CHAPTER

I INTRODUCTION ............. I Background .......... I 1

Theoretical orientation of the Study: Socially Mediated Inw formation and Attitude Change, . 2

The Influence of Authority . . . . 5

Variables Associated with Authority. 6

Survey of Previous Findings..... 8

Development of the Conceptual Hy potheses......... 10

Sumary of the Research Problem. . 12

II METHOD ............ 13

Design . . . . . . . . 33

variables.......... 22

procedure........... 25

II EINDINGS ........... . 33

Statement of Research Froblem. . . 33 
Student Sample. . . . . .

Tabulation of Pretest and Posttest Scores........

Effect of Pretest on Postest Scores ..........

Effect of Authority . . . .

Pretesting Effect... . . .

Effect of Authority on Attitude Change. . $\cdot \cdot \cdot \cdot \cdot \cdot \cdot$

Limitations and Recommendations

SETECTED BIBLIOGRAPHY $. . \cdot . \cdot \cdot \cdot \cdot \cdot \cdot \cdot \cdot \cdot$

A. TEACHER'S INSTRUCTIONS TO STUDENTS FIRST DAY OF EXPERIMENT • . . • • .

B. ALCOHOL ATTITUDE QUESTIONNATRE. • •

C. PERSONAL inEORMATION . . - . - .

D. TEACHER'S INSTRUCTIONS TO STUDENTS SECOND DAY OF EXPERIMENT (PRETEST, PHYSICIAN, POSTTEST EXPERIMENTAL CON= DITION) • • • • • . . . . • •

E. TEACHER'S INSTRUCTIONS TO STUDENTS SECOND DAY OE EXPERIMENT (NO PRETEST, CONTROI, GROUP, POSTTEST EXPERIMENTAL, CONDITION) . . . . . . . . . . 
F. TEACHER'S INSTRUCTTONS TO STUDENTS

SECOND DAY OF EXPERIMENT (NO PRETEST, SOCIAL WORKER, POSTTEST EXPERIMENTAL CONDTIION) .................

G. TEACHER'S INSTRUCTIONS TO STUDENTS SECOND DAY OF EXPERIMENT (NO PRETEST, PHYSICIAN, POSTTEST EXPERIMENTAL CONDITION ). . ................

H. TEACHER'S INSTRUCTTONS TO STUDENTS SECOND DAY OI EXPERTMENT (PRETEST, CONTROI, POSTTEST EXPERIMENTAL CONDITION) •

I. TEACHER'S INSTRUCTIONS TO STUDENTS SECOND DAY OF EXPERTMEIT (DRETEST, SOCIAI, WORKER, POSTTEST EXPERIMENTAL CONDTTION) •...............

J. PRETEST . .................

K. SPEECH GIVEN BY ACTOR TN EYPIRIMENTAL CONDTITONS, "PHE DETRTMENTAT EFELCTS OF ALCOHOL" . . . , . . . . . . . .

L. POSTTEST . . . . . . . . . . . .

M. PERSONAL INFORMATION - . . . . - .

N. THE STUDENT POPULATION • . • . . . .

O. IMPRESSIONS •. . . . . . . . . . 


\section{LIST OF TABLES}

TABLE

PAGE

I Experimental Conditions (Nis) . . . .

II Alcohol Attitude Questionnaire: Means and Standard Deviations By Experimental. Condition

III Analysis of Variance posttest Scores. .

IV Test for Significance of Differences Among Adjusted Means. . . . . . . . . 


\section{IIST OF FIGURES}

FIGURE

PAGE

1 Diagram of the Difference Between Direct and Indirect (Socially Mediated) Communication。 . 3

2. The "Offset Before-After" Design ...... 20

3 Minute by Minute Actions of the participant. 
CHAPTER I

\section{INTRODUCETON}

\section{BACKGROUND}

This research projece is an attempt to examine attitude change as it is influenced by the authority of the communicator. The researchers of the present study believe that one of ow foremost issues of concern for social workers should be: "How are we affecting those individuals with whom we work?" For men and women in a number of aifferent professions, such as doctors, lawyexs, social workors, and salesmen, influencing people is one of the primary aspects of their professional behavior. 1

Experience indicates that adaptation involves the majn-tenance of a dynamic balance between the needs of the people and the demands of "the system" of which they are a part. I'hus, social work often entails modifying or helping to charge aspects of "the system" or an individual's conception of him-. self, his view of others, and the attitudes of others towaxd nim.

Whe authors of this reseaxch project believe that the process of influence and attitude change is of significance

IJerone D. Frank, Persuasion and Healing Nes York: Schocken Books, 1963). 
to the practice of social work. Therefore, it is unfortunate that researchers in social work have infrequently dealt directly with this issue. This has been the case in spite of the fact that psychologists and social psychologists have written extensively on the subject for many years. It was with such considerations in mind that the present project was undertaken.

II. THEORETICAT, ORTENTATTON OF THE STUDY: SOCIALIY INDTATED TNFORMATION ANO ATITUDE CHANGE

For the most part, the preponderance of work on influence and attitude change has been done within the field of social psychology. Newcomb. Iurner, and Converse ${ }^{2}$ are one of a group of researchers who have written extensively on the subject of attitude change as an aspect of human interaction. Accoraing to them, "attitude change depends very generally on the receipt of new infomation that in some way or another is relevant to the attitude object from the point of view of the attitude holder." 3

Most researchers would agree that communication takes place in two ways: (1) directly, or (2) indirectly in a socially mediated form. When information is obtained directir, the receiver has a straightforward exposure to the subject

2Theodore $1 \mathrm{l}$. Newcomb, Ralph H. Turner, and philip E. Converse, Social Psychology (New York: Holt, Rinehart and winston, Inc. 1965).

${ }^{3}$ Ibid. D. 82 . 
matter. For example, an individual who is at the scene of an automobile accident and actually observes the incident is receiving information about the accident directly. In contrast, indirect or socially mediated information, is inform mation that is obtained secondhand from a source about the subject matter. 4 In this case, the individual having airect. Iy observed the automobile accident might relay his experience to a friend, probably trying to convince his fxiend of the severity and unpleasantness of his experience. The fxiend would then be receiving his information, socially mediated, from the individual who actually witnessed the accident. This distinction is illustrated by Figure 1.

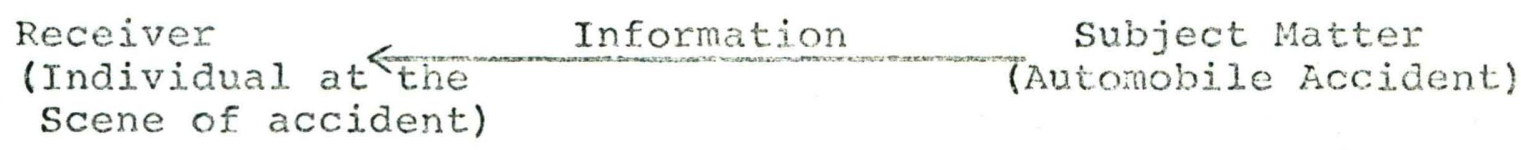

Receiver (Friend)

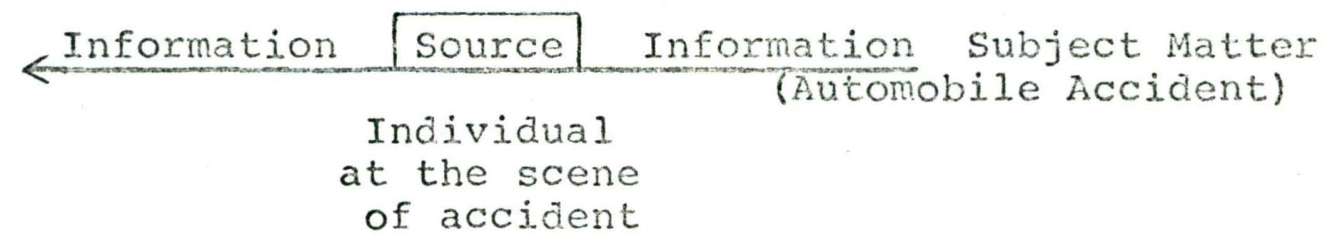

Figure 1. Diagram of the difference between direct and indirect (socially mediated) comunication.

Persuasion is a special case of attitude change where information relevant to the subject matter is communicated

${ }^{4}$ As Hovland, Janis, and Kelley (p. 19) point out, there are many types of sources. In this research project, "source" is an individual speaker who communicates directly to the receiver(s). 
to the receiver in a socially mediated form. "Typically, one party argues a point of view to another who remains essentialIy a 'silent partnex'."5 Research in the area of persuasive communication and attitude change has shown that there are three main classes of factors to consider in understanding a persuasive exchange: (1) characteristics of the receiver of the information, (2) characteristics of the message, itself, that is received in the form of irformation about the subject matter, and (3) characteristics of the source that is delivm ering the message. All of these factors are important for determining the effectiveness of a communication-how favorably or unfavoxably the message is received. In the present study, it is inferred that the higher an individual's score on an attitude instrument, the more favorably he has received the message.

The class of factors chosen for investigation in this research project is the characteristics of the source of a perm suasive communication. Research on the subject of attitude change $^{6}$ has shown that the evaluation of the source by the receiver affects his evaluation of the persuasive message,

5 Newcomb, Turner, and Converse, p. 94.

${ }^{6}$ In the present study, attitude change has not been ais. tinguished from the concept "opinion change." Research has shown that the relationship between these two concepts is an intimate one, and a distinction between the two has not been made by a majority of investigators. 
and consequently influences the likelihood of attitude change. ${ }^{7}$ Thus, it can be expected that when a source is evaluated highly, he will be better able to persuade his receiver to accept what he is saying than if he is evaluated less favorably.

III. THE INPJUENCE OF AUPHORITY

Many factors contribute to the evaluation of a source. Research in this area indicates that one of the most important factors in determining the effectiveness of a communication is the perceived authority of the source or communcator. ${ }^{8}$ As a result, the weight given the assertions of a source by its receiver(s) will depend on subfactors associated with authority; e.g., the amount of prestige and credibility attributed to the source.

Authority refers to "consensually supported power." 9

People accept the authority of an individual occupying a particular position because they respect his personal characteristics, they have regard for the position regardless of who

7H. G. Kelman and C. I. Hovland, "Reinstatement of the Communicator in Delayed Measurement of Opinion Change," I. Abnorm. Soc. Psychol., 43 (1953), pp. 327-335.

8 The present study has defined the term "authority" in terms of the perceived prestige and credibility of the source of a persuasive communication.

9 Newcomb, Turner, and Converse, p. 484. 
occupies it, or a combination of these. ${ }^{10}$ Thus, authority is derived from the hierarchy or status of a position and may have little to do with the knowleage and skills of the individual occupying the position. For example, research on prestige rankings of occupations over the years has frequently shown that the title of the occupation is what is actually being ranked, rather than the attributes of the individual occupying the position. Thus, the capabilities of the individual may have little to do with the authority he possesses or the amount of influence he has on others. In this study, it is assumed that two professionals, a physician and a social worker, are relevart sources of authority, although one may be considered more of an authority than the other. This hieraxchial arrangement of positions built into the social structure of society confers authority on its occupants by means of group norms. These norms are perpetuated and passed from generation to generation. Thus, the amount of prestige and credibility attributed to a profession may well be largely based on the prestige and credibility associated with the position, itself, and may therefore have little to do with the knowledge, ability, and skills of the individual.

IV. VARIABLES ASSOCIATED WITH AUTHORITY

1. Prestige

10 Newcomb, Iurner, and Converse, p. 484. 
Research on persuasive communications has shom that, in some instances, merely percesving a particular source as advocating the new opinion will be sufficient to inauce attitude change. This generally is referred to as "prestige suggestion," and in many experiments the expertise of the source is deliberately stressed. 11 There was a long line of experimental work in the early days of social psychology, under the category of "prestige suggestion." This work essentially showed that when the prestige of the source suggested high expertise, rather remaxkable information and viewpoints might be accepted by people whose information about the subject mat-ter was suffiajently low.

2. Credibility

Moxe often, however, a commulication includes auxiliary contents, such as appeals and arguments, which operate as incentives for inducing attitude change. In such instances, the nature of the source may affect the way in which the receiver(s) responds to these auxiliary incentives. Hovland, Janis, and Kelley have identified two important aspects of this situation: (1) the extent to which a communicator is pexceived to be a source of valid assertions (his "expertness") and (2) the degree of confidence in the commicator's intent to commicate the assertions he considers most valia (his

11s. F. Asch, "The Doctrine of Suggestion Prestige and Imitation in Social Psychology," Psychol. Rev, 55 (1943), pp. 250-276. 
"trustworthiness"). 12 These two elements, combined by Hovland, Janis, and Kelley, are referred to as the "credibility" of the source or communicatox.

\section{SURVEY OF PREVIOUS FTNDINGS}

1. Studies Concerning Source Credibility

Studies conducted over the past forty years have shown that the higher the credibility of the source of a persuasive communication, the greater the attitude change. ${ }^{13}$ In these studies, influence has been related to certain qualities at-.. tributed to the communicator by the receiver(s), which include: leadership, expertise, prestige, trustworthiness and impartiality. A number of studies have also shown that persuasive communications are the most effective when the re-

${ }^{12}$ Carl I. Hovland, Irving L. Janis, and Harold H. Kelley, Communication and Persuasion (1966) p. 21.

13M. Saadi and P. R. Farnsworth, "The Degrees of Acceptance of Dogmatic Statements and Preferences for rheir supposed Makers," J. Abnorm. Soc. Psychol., 29 (1934), pp. 143150 .

A. O. Bowden, E. F. Caldwell, and G. A. West, "A Study in Prestige," Am. J. Sociol, , 40 (1934), pp. 193-204.

R. K. Mexton, Mass persuasion: The Social Psychology of a War Bond Drive (ivew York: Karper, 1946).

C. I. Hovland, A. A. Iumsdaine, and F. D. Sheffield, Experiments on Mass Communication (Princeton Univ. Press, 1949).

P. H. Tannenbaum, "Initial Attitude Towara Source and Concept as Factors in Attitude Change Through Communication," pub. Opin. Quart., 20 (1956), pp. 413-425.

C. I. Hovland, I. I. Janis, and H. H. Kelley, Communication and Persuasion (New Haven and London: Yale Univ. Press, 1966). 
ceiver(s) is unaware of the commuicator's intent to persuade. 14

A major criticism of many of the studies that have been done in the area of source credibility and attitude change is that the subjects' evaluation of the source and content of the communication itself, must be "double mediated." For example, in a study by Hovland ard meiss, 15 instead of receiving a face-to-face socially mediated commication, receivers were presented the material in witten form, such that the linkage of source and content had to be made indirectly. Similarly, Kelman and Hovland ${ }^{16}$ presented a communication via recording of a radio program sexies, which again required the receiver(s) to make a non-visual linkage between the source and the subject matter.

Another fault, discussed by solomon, 17 is the fact that experimental studies in attitude change have failed to include a control group in their designs. As a result, it is virtually impossible to investigate either the effects of

${ }^{14} \mathrm{P}$. F. Lazarsfeld, B. Berelson, and H. Gaudet, The People's choice: How the Voter Makes up His Mind in a pres--
idential Campaign (New York: Duall, Sloan, and Pearce, 1944).

${ }^{15} \mathrm{C}$. I. Hovland, W. Weiss, "The Influence of Source Credibility on Communication Effectiveness," Public Opin. Quart., 15 (1951), pp. 635-650.

16 Kelman and Hovland, pp. 327-335.

17R. R. Solomon, "An Extension of Control Group Design," Psych. Bull. 46 (1949), pp. 137-150. 
the educational procedure or the influence of the attitude scale. In the present study, a control group is included.

2. Studies Concerning occupational prestige

Over the past thirty-ifive years, a multitude of studies have been conducted on the subject of occupational prestige, most of which have been simple ranking studies. Researchers have found that when occupations are ranked by the general American public, consistent differences emerge in the prestige assigned to different occupations. For example, the occupation of United States Supreme Court Justice has consigtently been ranked as one of the most prestigeful; occupations such as prostitute, garbage collector and shoe shiner have consistently been placed at the bottom of prestige scales. Clearly, there is consistency in the ranking of various occupations over the past thirty-five years. ${ }^{18}$

VI. DEVELOPMENT OF THE CONCEPTUA HYPOTHESES

The present study was undertaken to measure the degree

28 . Smith, "Proposals for Making a scale of Occupational Status," Sociology and Social Research, 20 (1.935), pp. 4049.

C. C. North and P. K. Hatt, "Jobs and Occupations: A Populax Evaluation," Opin. News, 9 (1947), pp. 3-13.

W. L. Warner, M. Meeker, and K. Eels, "Occupational Composition of Social Classes," Man, Work and Society (New York: Basic Books, Inc., 1962).

R. W. Hodge, P. Mo Siegel, and P. H. Rossi, "Occupational Prestige in the united States: 1925-1963," Class, Status and Power (New York: The Free Press, 1966), pp. 322-334.

I. G. Burchinal, "Agreement of Occupational Prestige as Ranked by Two Empirical Occupational Prestige scales," J. of Soc. Psychol., 50 (1959), pp. 335-340. 
of attitude change as a function of the "authority" of the source of a persuasive commication. In light of the previous research that has been done, specific hypotheses as to how the authority of the source influences the amount of at-.. titude change have been developed.

These hypotheses are:

1. The higher the perceived authority of the source of a. communication, the greater the attitude change.

2. Authoritatjve communications will produce signifi-cantly greater attitude change than will no communication at a11.

With these two hypotheses the study will evaluate the degree to which the perceived authoxity of two professionals (a physician and a social worker) influences the attitude change of subjects. Since physicians have consistently ranked higher in prestige than social workers, 19 we expect to find that the persuasiveness of the physician is greater than that of the social worker. There is, however, some indication that in recent years, as the field of social work has expanded, the gap in prestige rankings betweer the physician and the social workex may have somewhat narrowed. 20

\section{${ }^{19}$ See footnote 18.}

20 Kathleen Woodroofe, Fron Charity to Social Work (Lonoon: Routledge and Kegan, 1962). 
VII. SUMARY OF THE RESEARCH PROBLEM

In summary, the research evidence indicates that when socially mediated information is presented in an attempt to persuade, alter or change a receiver's attitudes toward cer.. tain issues, the nature and amount of change that can be expected to occur is significantly influenced by the authority (prestige and credibility) of the source or communicator.

Given the evidence that the physician has consistently been ranked significantly higher in prestige, albeit authority, than has the social worker, it is expected that the physician will be more successful in producing attitude change than will the social worker. In addition, it is expected that the visual presence of a communicator will enhance the acceptance of the ideas included in the message. Thus, more attitude change is expected to occur when the source is visibly present than when no authoritative source at all is attributed to a persuasive communication. 
CHAPTER II

METHOD

\section{DESIGN}

1. Choice of Alcohol Usage and Abusage as a Topic

The choice of alcohol usage and abusage for the message content arose by a process of elimination. To study the ef-fects of change, a topic was requirea that would be of interest to the subjects (high school students) but not over exposed to them through the media. It was felt that recentiy, - the psychomactive arugs, e.g., Is.S.D., heroire, barbituates, etc., had received a great deal of attention, especially with respect to concern about their usage among high school students. Alcohol usage was chosen, therefore, because it was an area of relevant concexn for high school students, and al.cohol, itself, has effects which recently have not been discussed to the extert that efrects of such drugs have.

A survey of current reading material was made for the location of subject matter that was relevant to the high school population and controversial enough to stimulate interest. A list vas made of various subjects related to alcohol and the frequency with which they appeared in some magazines. The survey included popular magazines such as 
Post, Life, and Newsweek that would be read and readily avail able to a high school population. The research literature also yielded a standardizca method of testing for alcohol knowledge and an alcohol attitude change questionnaire. Both were developed by the Division of Alcoholism, Alabama Department of Mental Health (Appendices $B, J$ and $L$ ). 21

High school sophomores were chosen because they are at the age (14-15) when alcohol becomes readily available to them from older peers. This, combined with their change to the newly acquired high school status, raises a multiplicity of questions about drinking alcohol and its effects. It was al. so felt that due to the subjects' ages, they would not have been previously exposed to a great deal of information about the effects of alcohol. They wexe to begin a health course sequence their sophomore year which would give them some information on alcohol; this would likely be their fixst form mal introduction to the topic of alcohol usage in an instructional setting.

The area of alcohol usage was also chosen because of its importance and concern to professionals such as social workers and physicians who frequently come into contact with

${ }^{21}$ George E. Passey and Dempsey $F$. Pennington, Jx., Tech niques for the Assessment of Selected Attitudes Tovard ATcow hol and Its Use, (Montgomery: Alabama Division of Alcoholism, 1968).

George E. Passey and Dempsey E. Pennington, Ir., Development of a scale for the Assessment of knowledge Concerning Alcohol and Its Use, (Montgomery: Alabama Division of Alcoholism, 1968). 
problems involving its consumption. In addition, probably more than ever before in history, a muttitude of controversial issues abounding within and among cultures has led to a confusing combination of factual and fictional information about alcohol usage. Finally, control of alcohol usage was tried unsuccessfully during the prohibition Fra. This emotional and legislative effort to influence its use was followed by an era when much was actually discovered about the medical ramifications of its usage.

The questionnaixe from the Alabama Comission on Alcohol-ism used in the study involves four areas of alcohol usage and of alcoholism:

\section{(1) Program Aspects}

a) Attitudes with respect to treatment of alcoholism.

b) Fruitfulness of treatment.

c) Whose responsibility is the treatment.

d) Funding of treatment programs.

e) Attitude with respect to education regaxding alcohol.

f) Professional training.

(2) Legal and Social Contiol

a) This section vas designed to determine the atti-tude of an individual toward a laissez-faire approach to the control of alcohol as a beverage and, at the other extreme, to a rigid prohibition of all alcoholic beverages. 


\section{(3) Attitude Toward Moderate (Social) Drinking}

Moderate use of alcohol is widely practiced among high school students, themselves. Specifically, the material examines what people within a defined population feel about such a practice.

\section{(4) Alcoholism and the Alcoholic}

This section was developed based on two ideas:

a) that the public attitude is critical to the behavior of the alcoholic, and,

b) that a population with adverse attitudes toward alcohol usage and the alcoholic would not likely accept infomation regarding such matters as the support of treatment facilities for alcoholics.

\section{The Control of Interaction Effects}

Studies on attitude change have, for many years, utili.zed the traditional pretest-posttest with control group de-sign, which controls for the main or primary effects of history (events occurring during the time span from the pretest to the posttest), maturation (effects occurring with the passage of time such as growing older, hungrier, or more tired), and the testing, (Hawthorne effect), itself. However, in recent years this design has been shown to contain a serious weakness when certain measuring instruments are used in the pretest. William D. Brooks, in a comparative study of this 
problem, has pointed out that this weakness is apparently an interaction effect of the pretest instrument with the expeximental variable. "When measuring instruments of a kind which may sensitize the subject in one way or another to the experimental variable are used in the pretest, the effect operates to contaminate the experimental results."22

In contrast to the main effects of testing, history, and maturation, which manifest themselves in mean differences independent of the presence of other variables, interaction effects are joint effects which may occur even when no main effects are present. 23 .

Campbell has said:

Applied to the testing variable, the in teraction effect might involve not a shift due solely or directly to the measurement process, but rather a sensitization of respondents to the experimental variable so that when $x$ was preceded by 0 there vould be a change, whereas both $x$ and $O$ would be without effect occurring alone. 24

Furthermore, sensitization, rather than creating the positive effects of producing a change in combination with the experimental variable, may also prevent detection of a

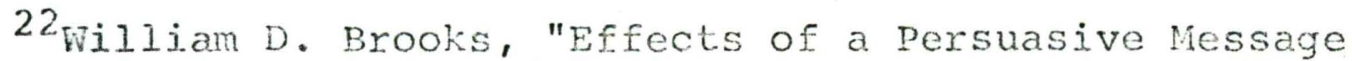
Upon Attitudes: A Methodological Comparison of an Offset Before-After Design with a Pretest-Posttest Design," The Journal of Comrunication, XVI 43 (Sept. 2966), pp. 180-188.

23 Ibid.

24Donald T. Campbell, "Factors Relevant to the Validity of Experiments in Social settings," Psych. Bull. (July 1954), pp. 297-312. 
change that might have otherwise occurred. Hovland, ${ }^{25}$ in his Army studies, found that the pretest reduced the effects of the experimental variable because of the elicitation of a commitment by the subject to a given position. Similarly, Solomon ${ }^{26}$ found that a speling pretest given to children reduced the effects of training. He presented an improvenent of the traditional pretest-posttest design to reduce the bi.asing effects of such interactions and demonstrated that the use of a three-uroup (one experimental and two control groups) design, and in some cases, a four-group (one experimental and three control groups) design can serve to substantially reduce interaction effects. Solomon ucilizes the term "interaction" with reference to what occurs when the pretest operates dixectly upon the txaining in a way that significantly reduces the effectiveness of the training period, itself. 27

Campbell, in his classic discussion of how extraneous

25 Hovland, Lumsdaine, and Sheffield, op. cit.

26 Solomon, pp. 137-150.

27Solomon, p. 141. "Interactions" include three areas of possible psychological biasing. First, Solomon points out that there is a great possibility that merely taking a pretest changes the subjects' attitudes toward the training procedures. Secondly, it may even change the "set" or attention factors important to the effectjveness of training. Finally, it may actually change the manner in which the subjects "perceive" the training material. 
variables affect experimental validity, pointed out that in opinion and attitude research, interview and attitude tests have been shown to be highly reactive. ${ }^{28}$ He stated that "In general, any measurenent procedure which makes the subject conscious or aware of the fact of the experiment can be suspected of being a reactive measurement." 29 In adition, he found that when the measurement process is not a part of the normal environment or is actually involved in the process being stuaied, it is probabiy reactive.

Recently, however, efforts have been nacie to control or at least reduce those interaction effects which have been shown to greatly limit the usefulness and validity of experiments conducted in social settings. Brooks ${ }^{30}$ has demonstrated in several studies the usage of a never research design, the "offset before-after" design as a possible solution for some of these problems. Brooks hypothesized: (1) that the "offset before-after" design can control the primary effects of extraneous variables as well as does the traditional design, and (2) that the "offset before-after" design will allow for measurement of the persuasive effect of a reactive measuring instrument separate from the effect of the experimental variable. Three groups were utilized in

$$
\begin{aligned}
& { }^{28} \text { Campbell, pp. 297-312. } \\
& { }^{29} \text { Ibia., p. } 299 . \\
& { }^{30} \text { Brooks, op. cit. }
\end{aligned}
$$


his stuay. Wwo groups comprised the traditional design; one with a pretest, stimulus, and a posttost; and the other with a pretest, no stimulus, and a posttest. The third group of subjects did not receive a pretest; instead, they simply heard the speech (the stimulus) and completed the posttest. The offset design utilized for the experiment is illustrated in Figure 2.

\begin{tabular}{lccc} 
& Pretest & Stimulus & Posttest \\
\hline Group A & $\mathrm{X}$ & $\mathrm{X}$ & $\mathrm{X}$ \\
\hline Group B & $\mathrm{X}$ & & $\mathrm{X}$ \\
\hline Group C & & $\mathrm{X}$ & $\mathrm{X}$ \\
\hline
\end{tabular}

Figure 2. The "Offset Before-After" Design

Brooks found that the "offset before-after" design controlled for the primary effects of extraneous variables, such as sex, age, and time of day as well as did the traditional design. More important, however, were the findings related to the interaction of the pretest with the experimental variable. Here, the direct attitude scale used was shown to be a reactive measuring instrument, based on the criteria from studies by Campbel $1^{31}$ and Crespi. ${ }^{32}$ The attitude scale used

${ }^{31}$ Campbe11, pp. 297-312.

32 I. D. Crespi, "The Interview Effect on Polling," pub. Opin. Quart., (1948), pp. 99-111. 
in Brooks' study was shown to be "reactive" in that the "offset before-after" subjects in Group C changed their attitudes significantly, while the pretest-posttest subjects in Group $B$ did not change their attitudes to an equal extent. Thus, the offset design allowed for a more sensitive assessment of the subjects' attitude changes than did the traditional pretestposttest design; i.e., jt registered a change in attitude that would not have been detected by the traditional design. In the traditional design, the subjects' attitudes (the phenomena being measured) would have been affected by the meas-uring instrument, but this effect would have been masked within the attitude change result.

To replicate the findings of Brooks' investigation, a second study was carried out at hcpherson College, Mcpherson, Kansas in 1963, ${ }^{33}$ utilizing the "offset before-after" design with college speech classes. The results and interpretation of the data were essentially the same as for Brooks' originm al experiment, verifying and substantiating his conclusions. From the results of these studies, it appeared that the weakness of the traditional design, when reactive instruments are used, was serious enough to warrant adoption of the offset design. That is, when one uses direct attitude scale instruments, which may be reactive, such as a questionnaire administered to a Iive audience, he ought to seriously con--

33 Brooks, pp. 185-186. 
sider the use of the "offset beforemafter" design, or some variant of it.

\section{A Modification of Brooks' Design}

The present investigation adop'ed a modified version of the offset design described by Brooks, based on the expecta. tion that an interaction effect would be obtained. The mod ified design uses six groups - two receive the "physician" stimulus, two receive the "social workex" stimulus, and two are control groups. All of the subjects received the post. test and the scores obtajned on the posttest became a base level of response for comparing the groups on attitude change. In Brooks' design, (Figure 2.) Group B did not take the posttest. In this study, it was assumed that the posttest scores would not differ from the pretest, since the time lapse between tests was only twelve minutes. It was assumed that the attitudes would not change by maturation in such a short time. However, since two different stimulus situations and two control groups were being utilized in the current study, the posttest scores were needed to provide a uniform base from which to compare all six groups. In addition, to control for the order of presentation in the three different experiment. al conditions, the order of pretest-no pretest situations were then alternated within the design.

\section{VARIABIES}

1. Definition of the Independent Variable 
Source prestige was one of the aspects of the independent variable selected for study. It was assumed that the high school students' evaluations of prestige would be in accord with the prestige evaluations of the general public in America. This assumption was based on the numerous studies reviewed earlier in this report that have been conducted over the years on prestige rankings of physicians and social workexs. ${ }^{34}$ This variable was, however, combined with Hovland, Janis, and Kelley's ${ }^{35}$ concept of credibility to constitute what the present investigators have termed "source authority." Source authority is the independent varjable which was exper-imentally manipulated in this study.

It was assumed that the credibility of the message source-"physician" or "social worker"-was established by the introduction the actor received from the teacher of the class in which he was delivering the message. Each teacher was briefed before the experiment and was given standardized written instructions for this introduction (see Appendix A). This provided uniformity and control for the possible effects that variations in instructions might have had on the students' responses to the communicator. The rationale for having the regular teachers introduce the communicator was based on the desirability of keeping the setting as natural as possible. It was assumed that utilizing the teachers for

\section{4} Hovland, Janis, and Kelley; op. cit. ${ }^{35}$ Ibia., p. 21. 
the introductions would make the situation less complicated and require a minimum of explanation beyond what was actually necessary for carrying out the experiment.

It was expected that the students had already accepted the teacher as a credible source due to their consistent exposure to and familiarity with him, and that this would function as a direct bridge for establishing the credibility and identity of the communicator. An inventory of teacher credibility was not taken, so there was no way of actually measuring this assumed relationship. However, comments from the students at the end of the experiment indicated that they had, in fact, accepted the actor as he was introduced by the teachers.

Source or communicator credibility, as the term was employed in this study, is comprised of two elements: (1) the extent to which a communicator is perceived to be a source of valid assertions (his "expertness") and (2) the degree of confidence in the communicator's intent to communicate the assertions he considers most valid (his "trustworthiness"). ${ }^{36}$ As previously noted, both factors are important for an audience's acceptance of the material being presented in any given communication.

2. Definition of the Dependent Variable The dependent variable, for this study, is the student's attitude toward alcohol usage, as measured by the paper-and36 Hovland, Janis, and Kelley, op. cit., p. 21. 
pencil instrument previously mentioned. Attitude change has been operationally defined as the difference between the scores obtained by each student on two equivalent forms of the same test, one version taken before the presentation by the actor, and the other taken irmediately following his presentation.

\section{PROCEDURE:}

\section{Sample}

\section{a) The students}

The groups for this study were drawn from the total nunber of sophomore students, approximately six hundred, in a high school which included a little over one-third of the secondary school population of an urban public school district. The groups were selected from biology classes, since all sophomore students were required to study biology, and the class sections were set up on a non-tracked basis. class assigmments of the students were determined on a student request basis, as well as factors affecting the actual. scheduling of classes. Thus, the sturents vere not assigned according to pre-detemined criteria such as an alphabetica? ordez or throngh the clustering of sections by other subject Inatter: j.o., membersip in language claseses in this particular high sohool would have el ininated certain students because they are onjy offoren at times when teachers are availabre. 
A personal information sheet (see Appendix C) was handed out to each student in these classes on the first day of testing at the school. The data indicated that the sex ratio of the sample used was almost equal, $51 \%$ male and $49 \%$ fernale. The age range shoved a very normal curve of the three years $(14,15$ and 16$)$ which were represented-13.5\% were 14 , $72.4 \%$ were 15 , and $14.1 \%$ were 16. A high percentage of the students (54\%) indicated that they had been active in some type of extracurricular organization the year before. The social organizations were identified as being the most popu1 ar.

The question regarding religion and attendance at a re-ligious service yielded interesting information. Of those who answered the guestion, 62.3\% considered themselves prow testant, 19.5\% Catholic, 16.4\% some other faith, and 1.9\% Jewish. The question of attendance at church showed $40.1 \%$ who attended regularly (weekly), 23.4\% seldom (holidays and special occasions), 16.8\% occasionally (less than weekly), and $19.8 \%$ never. Of the students who responded to the question regarding the grades they earned, $41.4 \%$ said they received $A$ and $B$ grades, $56.6 \% \mathrm{C}$ grades, and $2.4 \% \mathrm{D}$ and $\mathrm{F}$ grades.

An interesting contrast was found in the type of job the student was preparing for. Of those responding, $49.6 \%$ were preparing for a white collar job whereas only $31.5 \%$ of their fathers held such a position. The students indicated that $25.5 \%$ of them were preparing for a professional occupation 
requiring at least a college degree. Only $10.3 \%$ of their fathers and $8.8 \%$ of their mothers held such a job.

b) Familial Background

In the area of education, it was not surprising that the parents were fairly close to each other with $51.8 \%$ of the fathers and $65.1 \%$ of the mothers having completed at least a year of high school. One difference was found in the individual families: if the educational achievement of the father was less than high school, then generally the mother had one or two years more education, but if the father had any col.lege at all, the trend was reversed with the mother having 1-2 years less formal education. This trend followed in post college work: $7.0 \%$ of their fathers completed post college work but only $2.1 \%$ of their mothers had received such education. Political preference was fairly well split, but the mothers were more frequently Republican than the fathers. The income question was only answered by 69.1\% of the students-some responded with "it is none of your business." The results showed that $6.9 \%$ had an income of less than $\$ 4,000$, $34.5 \%$ had an income between $\$ 4,000-\$ 7,999,38.8 \%$ had an in come between $\$ 8,000-\$ 11,999$, and 19.8\% earned above $\$ 12,000$.

\section{The Actor}

A single actor was employed to assume both the social worker role and the role of physician. By having the same actor assume both roles, biases of the non-verbal sort such 
as gestures, voice intensity, pitch, tempo, and mannerisms, (which would be difficult either to repeat or measure) were reduced. Duncan, Rosenberg, and Finkelstein ${ }^{37}$ found that when different actors were utilized in a communicative situ. ation, "the transcribed paralinguistic and intonation behavjors functioned as significant cues and carried considerable influence, accounting for $52 \%$ of the variance in subjects' responses." 38

The present researchers had no way of actually measuring whether or not the actor did remain constant in his presen. tations and consistent in his verbal and non-verbal cues given. It was known, however, that the actor, who is actually a director of ministerial services in an institutional setting, felt that he functioned the same each time; indirectly con firming this, the lengths of the verbal presentations were very similar, being within one minute of each other.

3. Conduct of the Expeximent

The principal of the high school in which the expexi... ment was conducted, made the recommendation that biology classes should be used because of their non-tracking char-

${ }^{37}$ S. Duncan, Jr., M. J. Rosenberg, and J. Finkelstein, "The Paralanguage of Experimental Bias," Sociometry, 32 (1969).

${ }^{38}$ Ibid., p. 209. 
acter and their large size which would afford an adeguate sample. The six classroom situations were drawn from the thixd and fourth class periods of the day, taught by three biology teachers. The rationale for using these perioas in the school day was that by doing so, it was possible to reduce the attrition in the groups as well as other biasing factors that might have been introduced by using the extreme ends of the school day, that is, by using the first and sixth perioas. Natural classroon situations; i.e., actual rooms and teachers, were used to reduce the artificiality of the experimental set-up.

The first step in the experiment was a meeting, which was held with each of the teachers who were to be involved in the experiment. They were told the seguence of events, rationales, and the need for insuring that the students were not cued to the fact that an experiment was being conducted. The forms were explained and the time sequence and time Iimitations which would be involved in the handing out of the material was covered. Each of the teachers agreed to cooperate to the fuliest of their ability.

Two days later, the personal information sheet (Appendix C) and the alcohol knowledge instrument (Appendix B), were handed out to the three teachers before the third school period to reduce the experimenter's contact with students in the actual test situation. At the beginning of each period (3ra and 4th), roll was called in each class; then the know- 
ledge instrument was administered by the teachers. The teachers were asked to hand out the questionnaires first and then to explain that the students were bejng asked to fill them out as an information gathering device. The teachers were asked to answer no questions beyond explaining that the prom cedure was a method of gathering information. From all indications (student conversation and feedback from teachexs), the students were accepting and completed the questionnaires without comment. The time elapsed to complete the instrument was approximately twenty minutes for each class.

The personal information sheet (Appendix C) was administered by the teachers after the knowledge instrument had been collected. This form was explained as something that would be correlated with the information gathered on the knowledge questionnaire. Again, the reaction was minimal and accepting. This form was completed in approximately twenty minutes; thus, the full period was used to complete both forms. No student failed to have adequate time to complete them both.

One week later, the finai set of questionnaires were administeres. Each of the teachers received a list of the students who were to be moved from their room to another. No students were missed in this process. Calling of the roll and changing rooms took approximately four minutes. since the biology rooms are on the same floor and in the same school wing, the students did not have a great distance to travel. Then, each teacher read a different set of in 
structions to his class depending upon which stimulus the class was to receive. Pxetest administration, presentation of the speech or control (study time) condition, and posttest administration were accomplished. Verbal instructions to the teachers stressed that no questions were to be answered until the end of the posttest administration. The time sequence of the experiment is iliustrated by figure 3 .

THIRD PERTOD Minutes

\begin{tabular}{|c|c|c|c|c|}
\hline Participant & 510 & 15 & 30 & 45 \\
\hline Teacher 背1 & $\begin{array}{l}\operatorname{rosi} \\
\operatorname{casil}\end{array}$ & pretest & physician & $\begin{array}{l}\text { posttest ex- } \\
\text { planation }\end{array}$ \\
\hline Teacher 2 & $\begin{array}{l}\text { rolit } \\
\text { cali }\end{array}$ & pretest & $\begin{array}{l}\text { study } \\
\text { period }\end{array}$ & $\begin{array}{l}\text { posttest exw } \\
\text { planation }\end{array}$ \\
\hline Teacher \#3 & $\begin{array}{l}\text { roll } \\
\text { call }\end{array}$ & $\begin{array}{l}\text { social } \\
\text { workex }\end{array}$ & posttest & $\begin{array}{l}\text { explan- } \\
\text { ation }\end{array}$ \\
\hline
\end{tabular}

FOURTH PERIOD Minutes

\begin{tabular}{lllllllllll}
\hline Participant & 5 & 10 & 15 & 20 & 25 & 30 & 35 & 40 & 45 & 50 \\
\hline Teacher \#1 & $\begin{array}{l}\text { roll } \\
\text { call }\end{array}$ & study period postest $\begin{array}{l}\text { explan } \\
\text { ation }\end{array}$ \\
\hline Teacher \#2 & $\begin{array}{l}\text { roll } \\
\text { call }\end{array}$ & pretest social explan- free \\
worker ation & fres \\
\hline Teacher \#3 & $\begin{array}{l}\text { roll } \\
\text { call physician postiest explan- free } \\
\text { ation }\end{array}$ \\
\hline
\end{tabular}

Figure 3. Minute by minute actions of the participant. 
one of the experimenters used the last minutes of the class to explain to the students what had taken place. The third period group on the first day was told that they were part of a study to deternine how much they knew about alcohol, and theix cooperation was asked in not revealing to the fourth period class any of the material they had seen. They were told that they would receive a complete explanation the following day. Emphasis was placed on completing the questionnaires in order to draw attention away from the presenter. The experimenter did explain to the fourth period classes exactly what had taken place. On the following day, the first ten minutes of each of the thixd period classes were spent to explain what had happened in the experiment conducted the previous day. 


\section{CHAPTER TII}

\section{FINDINGS}

\section{STATENENT OF RESEARCH PROBIEM}

The present study was undertaken to measure the degree of attitude change as it is a function of the "authority" of the source of a persuasive communication. Past research in dicated that when socially mediated information is presented in an attempt to persuade, alter, or change a receiver's atti... tudes toward certain issues, the nature and amount of change that can be expected to occur is significantly influenced by the authority (prestige and credibility) of the source or communicator.

Given the evidence that physicians have consistently been ranked significantly higher in prestige, albeit authority, than have social workers, the experimenters expected to find in this study that the physician would be more successm ful in producing attitude change than would the social workex. In addition, it was expected that the visual presence of a communicator would enhance the acceptance of the ideas included in the message. Thus, more attitude change was expected to occur when the source was visibly present than when no authoritative source at 0.11 was attributed to a persuasive communication. However, further consideration has 
shown that this hypothesis (see Chapter II) is actually an extension of the first hypothesis. Therefore, the two hypotheses have been combined and will be treated as a single hypothesis.

As is mentioned in Chapter II, the experimenters were also concerned with the interaction effects of the pretest on the posttest; as a result, a modified version of Brooks' design was adopted. As the experimenters were using direct attitude scale instruments, which may be reactive (measuring the attitude of an individual often modifies the attitude) and two different sources of authority, it became advisable to adopt a method for determining if there was an interaction effect.

\section{STUDENT SAMPLE}

The experiment was conducted on two different days. The scores received by each student on the alcohol knowledge questionnaire were used to match the students, who were then randomly assigned to experimental conditions within each class period (see Appendix $\mathrm{N}$ for further discussion of the method used). As expected, there was some attrition of students on the second day of the experiment. An F test was conducted on the score each student received on the alcohol knowledge questionnaire. The results of the $\mathrm{F}$ test showed that there were no significant differences between any of the classes in the same period or in scores of the students when 
compared from one period to the next.

The total sample used in the experiment on both days was 140 students. These students were assigned to six different experimental conditions; the distribution of students in each experimental condition is given in Table $I$.

TABLE I.

EXPERIMENTAI, CONDTEIONSS

Questionnaires

Received.

Physician social Worker Control Total

Pretest and

Postest

24

22

27

73

\begin{tabular}{lcccc} 
Postest Onjy & 19 & 23 & 25 & 67 \\
\hline Total & 43 & 45 & 52 & 140 \\
\hline
\end{tabular}

\section{TABULATION OF PRETEST AND POSTTEST SCORES}

The questions used on the pretest and posttest attitude instruments were taken directly from Techniques for the Assessment of Selected Attitudes Toward Alcohol and Its Use, a pam phlet published by the Alabama Department of Mental Health. The wording of the questions was not changed except that for questions which asked specifically about the state of Alabama, the word 'Oregon' was substituted. There was a total of 60 questions on each test (both tests were shown to be equivalent forms). 
The maximum possible score on the pretest was 139. On the posttest the total possible score was 142.5 . The range of scores received by the students on the pretest was from 50.8 to 130.6 , and the range of scores on the posttest was from 51.3 to 134.5. The score means and standard deviations are prem sented in Table II. The top two rows are the pretest and posttest scores obtained from the same group of seventy-three students (see Table $I$ ). The bottom row contains scores obtained from the group of sixty-seven students who were administered only the posttest (see rable I).

TABLE II.

ALCOHOL ATTITUDE QUESTTONNATEE:

MEANS AND STANDARD DEVIATIONS BY

EXPERTMENTAL CONDITION

\begin{tabular}{|c|c|c|c|c|c|c|}
\hline & \multicolumn{2}{|c|}{ PHYSICIAN } & \multirow{2}{*}{$\begin{array}{l}\text { SOCIAL } \\
\text { mean }\end{array}$} & \multirow{2}{*}{$\begin{array}{l}\text { WORKER } \\
\text { stand. } \\
\text { dev. }\end{array}$} & \multicolumn{2}{|c|}{ CONTROI } \\
\hline & mean & $\begin{array}{l}\text { stand. } \\
\text { dev. }\end{array}$ & & & mean & $\begin{array}{l}\text { stand. } \\
\text { dev. }\end{array}$ \\
\hline Pretest & 99.2 & 18.1 & 102.2 & 15.1 & 109.2 & 11.9 \\
\hline Posttest & 103.4 & 20.5 & 104.2 & 16.1 & 109.9 & 15.6 \\
\hline $\begin{array}{l}\text { Posttest } \\
\text { No Pre- } \\
\text { test Con- } \\
\text { dition }\end{array}$ & 106.2 & 16.8 & 101.4 & 21.1 & 102.4 & 12.4 \\
\hline
\end{tabular}

It should be noted that there is a rank order of mean differences between pretest and posttest scores. In the physician condition, the difference between the students' 
scores was 4.2. In the social worker condition, the difference between the students' scores was 2.0 ; the control condition showed the least amount of change in scores represented at $\mathbf{7}$.

IV. EFFECT OF PRETEST ON POSTTEST SCORES

A modification of Brooks" expeximental design was adopted (see chapter II) to determine if there was any joint effect between: (1) having received or not having received the pretest, and (2) a particular experimental condition. Not only is there a question of such a joint effect interaction), but also the analysis will answer the question of whether or not there is a significant difference between all posttest scores (reactive effect of pretesting). An analysis of variance was used to answer these two questions. Referring to Table II, the bottom two rows (posttest scores of the two groups) were used in this analysis. The results of this analysis of variance of the posttest scores are given - in Table r.I. 
TABIE III。

ANALYSIS OE VARIANCE POSTTEST SCORES

\begin{tabular}{lcccc}
$\begin{array}{l}\text { Variance } \\
\text { Attributal To: }\end{array}$ & $\begin{array}{l}\text { Sum of } \\
\text { Squares } \\
\text { Freedom }\end{array}$ & $\begin{array}{l}\text { Eegree of } \\
\text { of Variance }\end{array}$ & F \\
$\begin{array}{l}\text { Total sum of } \\
\text { Squares }\end{array}$ & 47.9 & 5 & & \\
\hline $\begin{array}{l}\text { Experimental } \\
\text { Conditions }\end{array}$ & 11.4 & 2 & 5.7 & .42 \\
\hline $\begin{array}{l}\text { Pretest } \\
\text { No Pretest }\end{array}$ & 9.7 & 1 & 9.7 & .72 \\
\hline $\begin{array}{l}\text { Interaction } \\
\text { Intion }\end{array}$ & 26.8 & 2 & 13.4 & 13.5 \\
\hline
\end{tabular}

The analysis reveals that the interaction effect is not significant $(F=.99)$. Therefore, no joint effect prevailed between experimental conditions (physician, social worker, control) and whether or not a student received a pretest. Also, no significant diffexence was found between groups receiving or not receiving a pretest $(\mathrm{F}=.72)$. This is an interesting finding in light of previous research, and it will be discussed in the last chapter. Finally, the dif-ference between posttest scores of the groups in each of the three experimental conditions is not significant $(E=.42)$. 


\section{EFFECT OF AUTHORITY}

Since we have determined that there is no interaction between pretesting and experimental condition, we are now free to determine if perceived authority did have an effect on the attitudes of the students concerning the use of alcom hol. To determine this effect, the posttest scores from the three experimental conditions that received a pretest are compared, using an analysis of covariance, which adjusts the posttest mean scores to take into account the initial level of the pretest scores (compare Table II, top two rows). The experimental hypothesis is: The higher the perceived authority of a communicator, the greater the attitude change. It can be stated statistically as it is related to the posttest mean scores. This hypothesis assumes that the mean score in the physician condition will be greater than that in the social worker condition; in turn, the mean score of the social worker condition will be greater than that of the control group condition (MEAN $\underset{\text { physician }}{>} \underset{\text { social worker }}{>}$ MEAN

control). The null hypothesis is that the mean scores of the three experimental conditions will be equal (MEAN $=\underset{\text { MEAN }}{\text { social worker }}=\frac{\text { MEAN }}{\text { control) }}$.

The results of the analysis of covariance which was used to test the null hypothesis are contained in Table XV. 
TABLE IV。

TEST FOR SIGNIFICANCE OF DIFFERENCES

AMONG ADJUSTED MEANS

\begin{tabular}{|c|c|c|c|c|}
\hline $\begin{array}{l}\text { Variance } \\
\text { Attribu- } \\
\text { table To: }\end{array}$ & $\begin{array}{l}\text { Sum of } \\
\text { Squares }\end{array}$ & $\begin{array}{l}\text { Degrees of } \\
\text { Freedom }\end{array}$ & $\begin{array}{l}\text { Estimate } \\
\text { of Variance }\end{array}$ & $F$ \\
\hline $\begin{array}{l}\text { Total sum } \\
\text { of Squares }\end{array}$ & $19,407,944.6$ & 73 & & \\
\hline Pretest Scor & 13.0 & 2 & & \\
\hline $\begin{array}{l}\text { Residual sum } \\
\text { of Squares }\end{array}$ & n $19,407,931.6$ & 71 & & \\
\hline $\begin{array}{l}\text { Experimental } \\
\text { Conditions }\end{array}$ & 642.6 & 2 & 321.3 & .001 \\
\hline $\begin{array}{l}\text { Error (that } \\
\text { which is un- } \\
\text { explained by } \\
\text { above) }\end{array}$ & $19,407,289.0$ & 69 & $281,265.1$ & \\
\hline
\end{tabular}

The total sum of squares for the posttest scores is $19,407,944.6$, which is reflected in the top row of Table IV. This is the total sum of squares that will be broken down. As was mentioned earlier, the analysis of covariance takes into consideration how much correlation there is between the pretest scores and the posttest scores; in this case, it is determined to be a sum of squares of 13.0. This extremely small sum of squares (13.0) is interesting, since previous studies concerning attitude change indicated that there 
should be some correlation of pretest to posttest scores. There is a possibility, strongly suggested by this result, that the students marked the answers to the pretest form of the questionnaire randomly; i.e., they guessed.

The next row is the total sum of squares which is not explained by the effects of the pretest on the posttest but is explained by the different experimental conditions. As can be seen from the table of means (Table II), each expeximental condition has a different postest mean score. The difference among posttest mean scores is a sum of squares of 642.6. The sum, 642.6 , is subtracted from 19,407,931.6, leaving a sum of squares of $19,407,289.0$. This last number. is called an "error." The "error" is a reflection of indi.. vidual differences among the students.

The main effect of the experiment is related to the sum of squares of 642.6 . This score and the error sum of squares are divided by the degrees of freedom to yield estimates of variance. The error estimate of variance is di* vided into the estimate of variance from the experimental conditions to yield a ratio between what can be explained by the different experimental conditions and what cannot be explained by either the experimental condition or the pretest effects. The $F$ is extremely small, (F=.001). Therefore, we cannot reject the null hypothesis (MEAN $=$ MEAN physician social. worker $=$ MEAN control). Because we cannot reject this hypothesis, we must conclude that the experimental manipulation 
of perceived authority had no significant effect upon the students' attitudes toward the use and abuse of alcohol. 


\section{CONCTUSIONS}

This study was undertaken to measure the degree of attitude change as a function of the "authority" of the source of a persuasive communication. It was expected that a physician would have more success in affecting attitude change than a social workex, but, in this study, the results showed that in the physician condition, there was no significantly greater change in the students' attitudes. 'This research design pernitted the experimenters to examine the various effects the experimontal conditions and pretest would have on the results. Results showed that the pretest did not have an effect (reactive or correlation) on the posttest; there was no interaction effect in the experimental. conditions.

\section{PRETESTING EFEEC}

In Chapter III, section IV, it was found that the pretest did not have any significant effect on the outcome of the posttest scores (reactive effect). This finding is noteworthy in light of the finaings of earlier studies (Chapter II), which indicated the pretesting effect would likely affect the outcome of the posttest. The effect that is measured, when comparing the mean posttest scores of 
those who did receive a pretest with the means of those who did not, is related to the reactive feature of pretesting. However, the results indicated that there was no statistical difference between the posttest scores of the two groups. In the present study, there are two possible explanations for this finding. The students may not have been sufficiently stimulated (interest and curiosity aroused) by the information contained in the pretest to read it thoroughIy, therefore, they may have guessed at the answers. Another possibility is that the educational effort was too short in length to significantly influence the attitudes of the students in any of the groups.

The second question concerning the effects of the pretest on the posttest can be approached by referring to the results of the analysis of covariance. In Chapter II, it was pointed out that the pretest would have a direct effect on the posttest. In other words, if all of the students were given a pretest, it would be expected that a correlation between the pretest scores and the posttest scores would be found. Table IV shows that the variance attributed to the pretest scores $(13.0)$ is just a small fraction of the total sum of squares. Thus, it was expected that there would be some significant correlation between the students' pretest and posttest scores. The results, however, showed that in this study, there was no significant correlation between pretest scores and posttest scores. The reasons for this are, again, myriad, but the possibility that the students 
guessed on the pretest is strongly suggested.

II. ERFET OF AUTHORITY ON ATTITUDE CHANGE

There are several possible explanations to account for the finding that the students were not influenced to change their attitudes toward alcohol use and abuse. One such explanation is related to the fact that in this research project, the credibility of the teachors (see chapter II) was assumed. It is possible that for the students, the teachers were not as credible as they were assumed to be. It was not known for sure whether or not the students did accept the introductions and instructions given them by the teachers as credible, especially since the directions were at variance with everyday classroom procedure and subject content.

As indicated in Chapter I, a review of past and current literature was made to determine the prestige rankings of various occupations. The results were taken from various representative samples that provided an indication of how the general population ranked various occupations. Prestige ratings of occupations from the population utilized in this study were not obtained, thus, it is recomended that should this type of research he conducted again, the experimenters turn to the sample that they will be using and obtain, from them, their ranking of the various occupations. By taking the specific sample into consideration, the experimenters may find it feasible to use different occupa- 
tions and conduct an experiment utilizing more than two occupations. It is possible that other variables besides authority and prestige are affecting attitude change.

As was pointed out in Chapter. I, there is some indication that the prestige rankings of some occupations have changed in recent years. There are strong indications that the prestige of the occupation of social worker has changed considerably over a period of a few years. rhus, it is entirely possible that the students perceive little, if any, difference in the prestige of physicians and social workers.

\section{IIMITATIOISS AND RECOMMENDATIONS}

An evaluation of this research project revealed several limitations associated with the sample selected for study and the actual conduction of the experiment. First, the structure of the school day chosen was such that it was difficult to shift students from class to class and inpossible to shift them from one class period to the next. It was found that there were limitations as to the number of variables that could be controlled while still maintaining a laxge enough sample. The time schedule of the classroom situation also made it difficult to give effective instructions to the students before the tests so that they would not view the material as "just another assignment." The fifty-minute class periods did not provide the students with adequate time to absorb the naterial included in the questionnaires or speech. 
The topic that was used to determine attitude change was limited to what was thought to be controversial subject matter. It is felt that the population that is to be tested is likely the best source to deterrine what constitutes controversial subject material. It is possible that the topic(s) comprising the pretest should not be the same as that chosen to obtain the necessary information from the students for matching purposes (see Chapter II, aiscussion of sensitization).

Sophomores were presumed to be at an age where they would change their attitudes concerning alconol use or any other controversial subject more readily than any other group, i.e., juniors or seniors, in the high school setting. Two different age groups could be used to detemine at what age attitudes are more pliable.

The length of the educational effort concerning alcohol usage was extremely short, 10-1.1 minutes, such that the ideas presented to the students may not have been absorbed by them. Thus, it may be useful to lengthen the presentation. Another factor is the type of educational experience. The sample of students in this study received a dydactic (passive) educational effort, rather than one which would enlist thern as active participants, e.g., demonstrations, movies, anà role playing.

Another problem has to do with the content of the speech concerning alcohol usage. The speech utilized in this study was "slanted" toward the negative which may have 
caused some students to ignore what was being said. Research evidence (Chapter I, source "trustworthiness") has shown that "slanted" or one-sided communications (messages) are many times less persuasive, since the receivers may feel that the source has something to gain, personally, from having his ideas accepted. The addition of positive statements may also have the effect of gaining the attention of students who have already decided to use alcohol.

Attitude change, in this study, was measured over a very short period of time (pretest, stimulus, and posttest were administered on the same day). No attempt was made to determine if the changes in attitudes, if there had been any, were sustained or lost over a period of time.

\section{TMPTICATIONS}

As pointed out in Chapter $I$, the social work profession has infrequently dealt directly with the issue of influence (persuasion) as it is related to attitude change. The researchers of the research project believe that this is unfortunate, since social work directly involves the process of communication.

It has been indicated that social workers are concerned with the effects they are having upon those individuals with whon they work. Implications for the profession of social work not only point to the direct influence social workers may have upon their clients through direct casework methods, but also to the indirect influence. For 
example, the effectiveness of the social worker depends not only upon "what is said" or "how it is said," but, as pointed out in chaptex I, it also cepends upon "who says it" (authority). However, in this study it was shown that authority did not have a significant effect on producing attitude change. Thus, authority as it relates to the effectiveness of the social worker remains unanswered. It was found that several variables (length of presentation, etc.) may have affected the outcome of this study. Thus, professionals in the field of social work must become more aware of the variables that may be affecting their clients. There may be many variables that affect social work intervention that have yet to be explored.

\section{NEED FOR FURFHER RESFARCH}

The findings of this research project are not conclusive; adaitional research is needed. It is believed that the research design utilized in this stuay was solid and based on past work that has been done in the field of attitude change, and several of the weak areas in this study have been pointed out to be refined even further (length of presentation, speech). Additional research is needed to detemine if the authority of the communicator (source) does make a difference in the attitude change of the receiver.

The research represented in this study has made a contribution to the field of social work by pointing out 
areas of difficulty in actually determining the attitudes of individuals regariing any given piece of infornation that may be given to them (in the social work profession, the exchange of information is often between the client and the social worker).

The task undertaken in this research was to assess the effect authority has on changing the attitudes of students. As the findings presented in this study are not conclusive, a great deal of work is left to be done. What effect authority does have on producing attitude change remains in question. 


\section{SEIECTED BIBLIOGRAPHY}

Asch, S. E., "The Doctrine of Suggestion prestige and Imitation in Social Psychology," Psychol. Rev. , 55, 1948, pp. 250-276.

Bowden, A. O., Caldwell, F. F., and west, G. A., "A study of Prestige," American J. Sociol., 1934, pp. 193-204.

Brooks, William D., "Effects of a Persuasive Message Upon Attitudes: A Methodological Comparison of an Offset Before-After Design with a Pretest-posttest Design," The Journal of Cornunication, Vol. XVI, \#3, September $1966, \mathrm{pp}, 180 \cdots 138$.

Burchinal, Lee G., "Agreement of Occupational Prestige as Ranked by Two Empirical Occupational Prestige Scales," The J. of Soc. PSy., 1959, pp. 335-340.

Campbeil, Donald T., "Factors Relevant to the Vaijdity of Experiments in Social Settings," Psych. Bull. "July 3.954, pp. 297-312.

Crespi, L. P., "The Interview Effect on Polling," Pub. Opin. Quart., 1948, pp. 99-111.

Duncan, Starkey, Jr., Rosenberg, Milton J., and Finkelstein, Jonathan, "The Paralanguage of Experimenter Bias," Sociometry, June 1969, pp. 207-219.

Frank, Jerome D., Persuasion and Healing, New York: Schocken Books, 1963.

Hodge, Robert W., Siegel, Paul M., and Rossi, Peter H., Occupational prestige in the united States: 1925-1963; Class, status and Power, New York: The Free Press, $1966, p p \cdot 322-334$.

Hovland, Carl I., Janis, Irving L., and Kelley, Harold H., Communication and Persuasion, New Haven and London: Yale Univ. Press, 1966.

Kelman, H. C., and Hovland, C. I.. "Reinstatement of the Communicator in Delayed Measurement of Opinion Change," J.Abnorm. Soc. Psychol. 48, 1953, pp. 327-335. 
Lazarfeld, P. F., Berelson, B., and Gaudet, Hazel, The People's Choice: How the Voter Makes Up His Mind In a Presidential Campaign, New York: Duali, SIOan and Pearce, 1944 .

Merton, R. Ke, Mass Persuasion: The Social Psychology of a War Bond Drive, New York: Harper, 1946.

Newcomb, Theodore $M_{0}$, Turner, Ralph $H_{*}$, and Converse, Phil.. ip E., Social Psychology, New York: Holt, Rinehart, and Winston, Inc., 1965.

North, C. C. and Hatt, P. K., "Jobs and Occupations: A popular Evaluation," Opin. News, 9, 1947, pp. 3-13.

Passey, George E. and Pennington, Dempsey F., Ir., Develop. ment of a Scale for the Assessment of knowledge Concerning Alcohol and Its Use, Montgomery: Alabama Div ision of Alcoholism, 1968 .

Passey, George E, and Pennington, Dempsey F., Ir., Techniques for the Assessment of Selected Attitudes Toward Alcohol and Its Use, Montgomery: Alabama Division of Alcoholism, 1968 .

Saadi, M. and Farnsworth, P. R., "The Degrees of Acceptance of Dogmatic Statements and prefexences for theix supm posed Makers," J. Abnorm. Soc. Psychol. 29, 1934, pp. $143-150$.

Smith, Mapheus, "Proposals for Making a Scale of Occupational. Status," Sociology and Social Research, 20, 1935, pp. $40-49$.

Tannenbaum, P. H., "Initial Attitude Toward Source and Concept as Factors in Attitude Change Through Communication," Pub. Opin. Quart. 20, 1956, pp. 413-425.

Warner, W. I., Meeker, Marcia, and Eells, Kenneth, "Occupa-tional Composition or Social Classes," Man, Work and Society, New York: Basic Books, Inc., 1962.

Woodroofe, Kathleen, From Charity to Social Work, London: Routledge and kegan, Paul, 1962. 


\section{GENERAL BIBLIOGRAPHY}

Alcohol Education in oregon Public Schools; Staff of the Alcohol Studies and Rehabilitation Section, Mental Health Division of the Oregon state Board of Control and the State Dept. of Education, Salem, Oregon, 1963.

Alexandex, C. Norman, Jre, and Harrison, G. Weil, "players, Persons and purposes: Situational Meaning and the Prisoner's Dilemma Game," Sociometry, Albany, New York: The American Soc. Association, Boyd Printing Co., Inc., June 1969, Vol. $32 \# 2$, pp. 121-144.

Allyn and Festinger, "The Effectiveness of Unanticipated Persuasive Communication," J. Abnorm. Soc. Psy., 1961, pp. $35-40$.

Anderson, W. A., "Occupational Attitudes and Choices of a Group of College Men," Social Forces, 4, December 1927. \#2,

Baltzel1, E. Digby, "Who's who in Amexica" and "The Social Register," Class, Status and power, New York: The Free Press, 1966, pp. 266-275.

Berenda, Ruth w., The Influence of the Group on the Judgments of Children, New York: King's Crown Press, 1950.

Brembeck, Winston Lamont and Howell, William Shirley, Persuasion: A Form of Social Control, New York: Prentice-Hall, 1952 .

Burgess, "Statistics and Case Studies as Methods of Social Research," Sociology and Social Research, XII, 1927, pp. $1.13-114$.

Burtt, $H_{.}$E, and Falkenburg, D. R, Jr., "The Influence of Majority and Expert Opinion on Religious Attitudes," J. Soc. Psychol, 14, 1941, pp. 269-278.

Chodorkoff, Bernard, PhD., "Alcohol Education in Psychiatric Institute," Quart. Jour. of Studies on Alcohol, 28, 4: $1967, \mathrm{pp} .723-730$.

Counts, G. S., "The Social status of Occupations," School Rev., 1925. 
Davies, A. E., "Prestige of Occupations," Man, Work and Society, New York: Basic Books, Inc., 1962, pp. 255-268.

Doob, L. W., Public Opinion and Propoganda, New York: Holt, 1948.

Duncker, K., "Expeximental Modification of Children's Food. preferences Through Social Suggestion," J. Abnorm. Soc. Psychol., 33, 1948, pp. 489-507.

Fishbein, Martin, Readings in Attitude Theory and Measurement, New York: John Wiley and Sons, Inc., 1967.

Gerald, Harold B., "Disagreement with others, Their credibility, and Experienced Stress," Journ. Abnormal and Social Psychology, 62, 1961, pp. 559-564.

Hartmann, G. W., "The Occupational prestige of Representative Professions," Psych. Bull. 1934.

Hites, R. W. and Campbell, D. T., "A Test of the Ability of Fraternity Leaders to Estimate Group Opinion," J. Soc. psychol., 32, 1950, pp. 95-100.

Hyman, Gerbert, Survey-Design and Analysis, Glencoe: The Free Press, 1955 .

Insco, Chester A., "One-Sided Versus Two-Sided Communications and Counter-communications," Journ. Abnorm. and Social Psychology, 65, 3; 1962, pp. 203-206.

Jahoda, Marie and Warren, Neil, Attitudes, Baltimore, Ma.: Penguin Books, Inc., 1966.

Jones, Edward E., Davis, Keith E., and Gergen, Kenneth J., "Role playing Variations and Their Informational Value for Person Perception," J. of Abnorm. and Soc. Psy., Vol. 62, \#2, 1961, pp. 302-310.

Katz, Daniel, "The Functional Approach to the Study of Attitudes," Pub. Opin. Quart.' 1960, pp. 163-204.

Kelman, Herbert C., "Compliance, Identification and Internalization: Three Processes of Attitude Change," J. of Conflict. Resolution, 1958, pp. 51-60.

Kulp, D. H., II., "Prestige, as Measured by Single-Experience Changes and Theix Permanency," J. Educ. Res., 27, $1934, \mathrm{pp} .663-672$. 
Lazarsfeld, P. F., Berelson, B., and Gavdet, Hazel, "The Nature of Personal Influence," Readings in General Soc., p. 281.

Lazarsfeld, Paul F., Sewell, William H., and Wilensky, Haxold L., The Uses of Sociology, New York: Basic Books, Inc., 1967 .

Lewis, Helen B., "Studies in the Principles of Judgments and Attitudes: IV., the Operation of Prestige Suggestion," J. Soc. Psychol., 14, 1941, pp. 229=256.

Maccoby, Eleanor E., Newcomb, Theodore M., and Hartley, Eugene L., Readings in Soc. Psy. , New York: Holt, Rinehart and Winston, Inc, 1958 .

Merton, R. K., "patterns of Influence and of Communications Behavior in a Local Community," in F. F. Lazarsfeld and F. N. Stanton, eds., Communications Research, New York: Harper, 1949 , pp. $180=219$.

Osgood, C. E. and Stagner, R., "Analysis of a Prestige Frame of Reference by a Gradient Technique," Journal of Applied Psychol.: 25, June 1941, pp. 275-390.

Papageorgis, Demetrios, "Bartlett Effect and the Persistence of Induced Opinion Change," Journ. Abnorm. and Social Psychology, 67, 1: 1963, pp. 61-67.

Reiss, Albert J., Jr., Occupations and Social Status, New York: The Free press of Glencoe, Inc., 1961.

Riely, Matilda white, Sociological Research I: A Case Approach, New York: Harcourt, World and Brace, Inc., 1963.

Smith, Mapheus, "An Empiracle Scale of Prestige Status of Occupations," Man, Work and Society, New York: Basic Books, Inc., 1962, pp. 269-273.

Solomon, R. R., "An Extension of Control Group Design," Psych. Bul1., 1.949, pp. 137-150.

Stewart, F. A., "A Sociometric Study of Influence in Southtown," Sociometry, 10, 1947, pp. 11-31.

Weiss, Walter, "Opinion Congruence with a Negative Source on One Issue as a Factor Influencing Agreement on Another Issue," Jour. Abnormal and Social Psychology, 54, 1957, pp. $180-\longdiv { 8 6 }$. 
Weiss, Walter, "The Effects of a Communication on Attitude Change and Scale Judgements," Jour. Abnormal and Social. Psychology, 62, 1, 1961, pp. 133-140.

Wilson, Stephen R., "The Effect of the Laboratory Situation on Experimental Discussion," Sociometry, June 1969, pp. $220-236$.

Young, P. G. and Schmid, C. F., "The Use of Historical Data in Social Research," Scientific Social Surveys and Research, V., 1926, pp. 148-266. 


\section{APPENDIX A}

\section{TEACHER'S INSTRUCTIONS TO STUDENTS}

FIRST DAY OF EXPERIMENT

Today, we have a questionnaire that we would like you to fill out. The questions are a part of a study concerning high school sophomores and what they know about alcohol use. Your names are asked on the forms only as a way of correlating the material.

On Personal Information Sheet:

Question \#5 - please list the organizations you are a member of; do not mark in spaces. 
APPENDIX B

ALCOHOL ATTITUDE QUESTIONNAIRE

Name last

The following questions are to be completed as quickly as possible. Do not skip any questions but answer each one. Work quickly, do not leave any questions unanswered, return to any to check your answers. If you must guess to answer, do so. When you are finished turn your paper over.

True False

1. During the prohibition era excessive drinking was principally regarded as a moral issue.

2. Most of the diseases of alcoholism are caused by improper diet and hygiene.

3. The temperate use of alcohol, provided a normal diet is maintained, cannot produce disease.

4. Natural fermentation of the sugars of fruits is the process of making wine.

5. Whiskey containing $80 \%$ alcohol is described as being 80 proof.

6. Members of Alcoholics Anonymous admit they cannot control their drinking of alcohol.

7. Children of alcoholics seem more likely to become alcoholics themselves than do children of moderate drinkers.

8. One-fifth to one-third of all alcoholics in the United States are women.

9. Authorities estimate that there are 700,000 female alcoholics in the United States today. 
True False

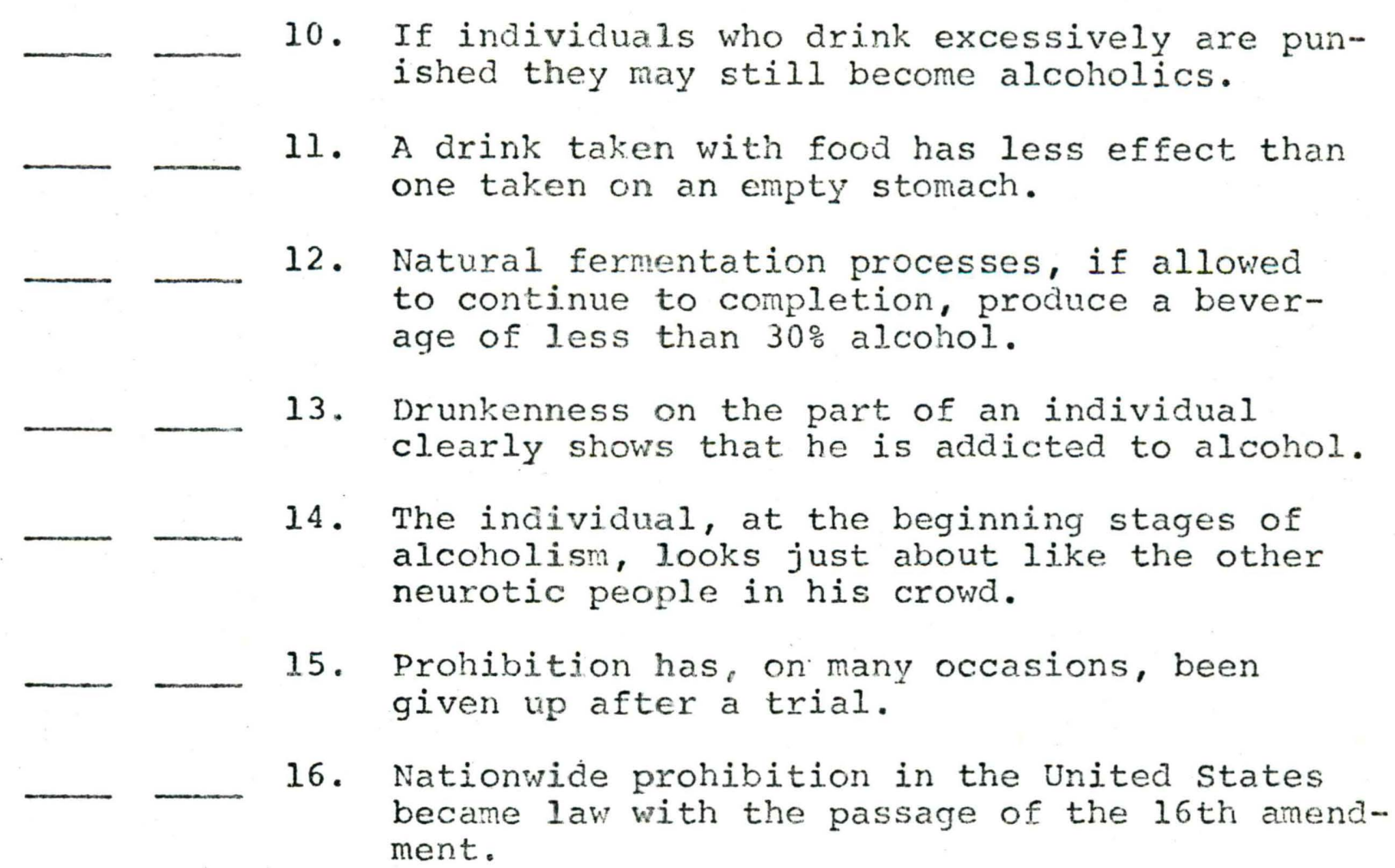
ment.

17. Distilled spirits did not make their appearance in Europe until the 15th century.

18. All churches condemn drunkenness but not all require their members to be abstainers.

19. The membership of Alcoholics Anonymous is restricted to those who cannot otherwise afford treatment.

20. An individual who has been taking the drug, Antabuse, is able to drink moderately.

21. The individual who has "lost control" wi.th regard to his drinking is likely to become an extravagant spender.

22. Antabuse is a drug which a wife could use to help cure her husband's drinking without his being aware of it.

23. The everyday use of alcoholic beverages was accepted in early America.

24. The drug, Antabuse, is habit forming just as is morphine. 
True False

$$
\begin{aligned}
& \begin{array}{l}
\text { 25. Alcoholics Anonymovs is a reformer's group. } \\
\text { 26. Almost all vegetable substances are sources }
\end{array} \\
& \text { of alcohol. } \\
& \text { 27. Children of moderate drinkers have mental } \\
& \text { disorders more often than do children of ab- } \\
& \text { stainers. }
\end{aligned}
$$


True False

40. Alcohol acts as a typical narcotic.

41. When an individual who has been taking the drug, Antabuse, cirinks even a small amount of alcohol he becomes violently ill.

42. Alcohol is described medically as a stimulant.

43. A person who drinks a pint of whiskey a day receives less than one-fourth of his daily calory needs.

44. Wines are fortified by adding additional alcohol after fermentation is stopped.

45. In the $1850^{\prime}$ 's, prohjbition laws were adopted in 13 states.

46. Alcoholics Anonymous believes that once a person becomes an alcoholic, he will always remain an alcoholic.

47. Most alcoholics like the taste of liquor.

48. Most alcoholics hate themselves for their lack of ability to stop drinking.

49. By 1863, only one state still had a prohibition law.

50. Alcohol relieves tension and relaxes the individual just as other sedatives do.

51. The original purpose of taxing alcoholic beverages was to gain revenue and only incidentally to limit consumption.

52. Alcoholics Anonymous actively recruits members.

53. "Beer heart" is caused by the action of excess alcohol on the heart muscle.

54. Experts have noted that the tendency of lower-middle class people to abstain from drinking is often to distinguish themselves from the lowest social class.

55. Most drinking among high school students is of beer and wine. 
True False

56. Vomiting following the intake of a great deal of alcohol is caused primarily by the continuous odor present.

57. One of the principle reasons for drinking alcoholic beverages in Europe during the midale ages was the lack of safe arinking water.

58. A large person requires about the same amount of alcohol to become "tight" as does a small person.

59. Sufficient alcohol to reduce a person's unpleasant feelings will also eliminate all of his other feelings.

60. Alcoholics Anonymous believes that the alcoholic must become a total abstainer.

61. Small amounts of alcohol usually reduce one's ability. to make judgment, particularly about himself.

62. The tendency to become an alcoholic is apparently inherited.

63. Withholding money from the alcoholic is usually helpful in curing him.

64. Brain wave patterns of alcoholics are somewhat different from those of non-alcoholics.

65. Individuals who have traveling jobs become alcoholic more often than those who have jobs which allow them to live at home.

66. About $50 \%$ of the alcoholics in the United states are women.

67. Most alcoholics appear for treatment only after some physical or psychological crisis has occurred.

68. Alcohol affects physical skills before it affects mental abilities of the drinker.

69. Native white Americans show a relatively low rate of alcoholisin.

70. A limited amount of alcohol before eating will act as a mild stimulant to the stomach 
True False

and hence to the appetite.

71. Going "on the wagon" is necessary to the rehabilitation of the alcoholic.

72. Most alcoholics appear for treatment only when the illness is in an advanced stage.

73. Alcoholism is a disease which gets progressively worse.

74. There are very few Jewish people who are alcoholics.

75. Liquors are produced by distilling naturally fermented drinks to obtain a high percentage of alcohol.

76. In the early stages of alcoholism the individual can control the amount he drinks on any occasion.

77. When the individual goes from social drinking to alcoholism, one can clearly see the change in that person.

78. Mass drunkenness in religious observances is found in many private societies.

79. Alcoholism is as common in rural areas as it is in cities.

80. In preparing beer, the fermentation process is stopped before it is complete.

81. In the so-called conditioned response method of treatment, a ärug which produces vomiting is given along with some alcoholic beverage.

82. Alcoholics Anonymous emphasizes that the alcoholic must refuse even the smallest amounts of alcohol in any form other than medical.

83. Poles show a very low rate of alcoholism.

84. Less than one-fourth of the money spent for alcoholic beverages goes to the government for taxes.

85. In the early days of our country, a person was fined or jailed for drunkenness.

86. Alcohol has no real effect on a person's 
True False

feelings of shame and remorse.

87. In all societies in the world where alcoholic beverages are know, drinking accompanies holiday activities. 


\section{PERSONAL INFORMATION}

A. Personal Data:

1. Initials

2. Age Month Year

3. Sex: Male Female

4. How many school organizations in the last school you attended were you a member of (clubs, church groups, etc.)?

5. Of the organizations above, how many were primarily: social professional hobby religious social action service political other (explain)

6. In which of the above organizations were you the most active?

7. What is your religious preference? Protestant Catholic Jewish Other (specify)

8. How often do you attend religious neetings? 


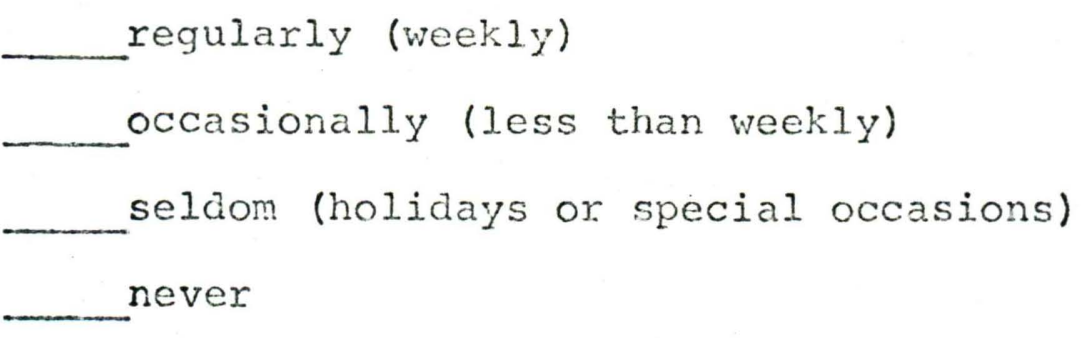

9. What occupation are you preparing yourself for?

10. What are your immediate plans after finishing high school? work technical or vocational school. college military other (specify)

11. The grades I get are mostiy $A$ and $B$ C $D$ and $\mathrm{F}$

12. Have you attended any school outside of the salem area? yes no

13. Give the state and city (town) where you were born city state

B. Family Data: 
1. Age of youx

father

mother

2. Do you have any brothers or sisters?

yes

no

3. What is the highest level of education completed by father

(give by numbers, i.e., one year of colmother lege $=13$ )

4. What is your father's usual or most frequent occupation?

(if deceased or retired, give last occupation)

5. What is your mother's usual or most frequent occupation?

6. Political preference of your father Democrat

Republican

other (specify)

7. Give political preference of your mother Democrat

Republican

Other (specify)

8. What is your father's approximate income?

$\longrightarrow \quad 0-\$ 3,999$ per year 


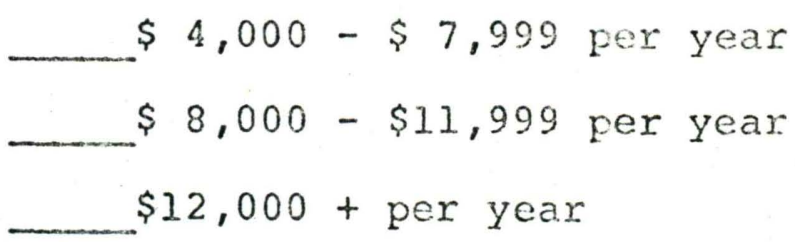

9. In the last five years, how many city to city moves has your family made

10. In the last five years, how many moves within the same city has your family made 
TEACHER'S INSTRUCTIONS TO STUDENTS

SECOND DAY OF EXPERIMENT

(PRETEST, PHYSICIAN, POSTIEST FXPERTMENTAL CONDITION)

Teacher says to students:

I'm sure you have noticed that today, some of you are in different classes than you were last week when you were given the Alcohol Knowledge Questionnaire; we have regrouped you according to the scores you received. Let me reassure you that everyone scored very highly on the questionnaire, and I am very pleased with the results. The classroom arrangements for today are only temporary and you will be returning to your regular classes tomorrow.

1. Today, I have another questionnaire I would like to have you fill out. (Give them ten minutes to complete them).

2. Now, I would like to introduce our guest speaker for today. This is (Dr. Adams) who is a practicing physician in the Portland area. He will speak to you today on the topic of alcoholism. Please do not ask any guestions or make comments during the speech. Time has been provided at the end of the period for this purpose. (step \#2 should take about fifteen minutes).

3. Before our question and answer period, I would like to have you complete a final questionnaire. (Give them ten minutes).

4. Question and answer period. 


\section{TEACHER'S INSTRUCTIONS TO STUDENTS \\ SECOND DAY OF EXPERIMENT \\ (NO PRETEST, CONTROI, GROUP, POSTTEST EXPERIMENTAL CONDITION)}

Teacher says to students:

I'm sure you have noticed that today, some of you are in different classes than you were last week when you were given the Alcohol Knowledge Questionnaire; Let me reassure you that everyone scored very highly on the questionnaire, and I am very pleased with the results. The classroom arrangements for today are only temporary and you will be returning to your regular classes tomorrow.

1. Today, I would like you to spend the next twenty-five minutes or so studying on your own. Please do not ask any questions or make comments about questionnaires you were asked to fill out last week or about the classroom arrangements for today. Time has been provided at the end of the period for this purpose. (Give them twenty-five minutes to study).

2. Now, before our question and answer period, I would like to have you complete a final questionnaire. (Give then ten minutes) .

3. Question and answer period. 


\section{TEACHER'S INSTRUCTIONS TO STUDENTS \\ SECOND DAY OF EXPERTMENT \\ (NO PRETESTi', SOCTAL WORKER, POSTTEST EXPERIMENTAI CONDITION)}

Teacher says to students:

I'm sure you have noticed that today, some of you are in different classes than you were last week when you were given the Alcohol Knowledge Questionnaire; we have regrouped you according to the scores you received. Let me reassure you that everyone scored very highly on the questionnaire, and I am very pleased with the results. The classroom arrangements for today are only temporary and you will be returning to your regular classes tomorrow.

1. Today, I would like you to spend the next ten minutes or so studying on your own. (Give them ten minutes to study).

2. Now, I would like to introduce our guest speaker for today. This is Mr. Adams, who is a professional social worker, working with alcoholics in the Portland area. He will speak to you today on the topic of alcoholism. please do not ask any questions or make comments during the speech. Time has been provided at the end of the period for this purpose. (Step \#2 should take about fifteen minutes).

3. Before our question and answer period, I would like to have you complete a final questionnaire. (Give them ten minutes).

4. Question and answer period. 


\section{APPENDIX G}

\section{'TEACHER'S INSTRUCTIONS TO STUDENTS}

SECOND DAY OF EXPERIMENT

(NO PRETEST, PHYSICIAN, POSTTEST EXPERIMENT CONDITION)

Teacher says to students:

I'm sure you have noticed that today, some of you are in different classes than you were last week when you were given the Alcohol Knowledge Questionnaire; we have regrouped you according to the scores you received. Let me reassure you that everyone scored very highly on the questionnaire, and I am very pleased with the results. The classroom axrangements for today are only temporary and you will be returning to your reg ular classes tomorrow.

1. Today, I would like you to spend the next ten minutes or so studying on your own. (Give them ten minutes to study).

2. Now, I would like to introduce our guest speaker for to day. This is Dr. Adams who is a practicing physician in the Portland area. He will speak to you today on the topic of alcoholism. Please do not ask any questions or make comments during the speech. Time has been provided at the end of the period for this purpose. (step \#2 should take about fifteen minutes).

3. Before our question and answer period, I would like to have you complete a final questionnaire. (Give them ten minutes) :

4. Question and answer period. 


\section{APPENDIX H}

\section{TEACHER'S INSTRUCTIONS TO STUDENTS \\ SECOND DAY OF EXPERIMENT \\ (PRETEST, CONTROL, POSTTEST EXPERIMENT CONDITION)}

Teacher says to students:

I'm sure you noticed that today, some of you are in different classes than you were last week when you were given the Alcohol Knowledge Questionnaire; we have regrouped you according to the scores you received. Let me reassure you that everyone scored very highly on the questionnaire, and I am very pleased with the results. The classroom arrangements for today axe only temporary and you will be returning to your regular classes tomorrow.

1. Today, I have another questionnaire I would like to have you fill out. (Give them ten minutes to complete them).

2. Now, I would like you to spend the next fifteen minutes or so studying on your own. (Give them fifteen minutes to study). Also, tell them not to ask any questions or make any comments about the questionnaires they have been asked to fill out. Time has been provided at the end of the period to answer any questions you may have.

3. Before our question and answer period, I would like to have you complete a final questionnaire. (Give them ten minutes).

4. Question and answer period. 
TEACHER'S INSTRUCTIONS TO STUDENTS
SECOND DAY OF EXPERIMENT
(PRETEST, SOCIAL WORKER, POSTTEST EXPERIMENT CONDITION)

Teacher says to students:

I'm sure you have noticed that today, some of you are in different classes than you were last week when you were givm en the Alcohol Knowledge Questionnaire; we have regrouped you according to the scores you received. Let me reassure you that everyone scored very highly on the questionnaire, and I am very pleased with the results. The classroom arrangements for today are only temporary and you will be returning to your regular classes tomorrow.

1. Today, I have another questionnaire I would like to have you fill out. (Give them ten minutes to complete them).

2. Now, I would like to introduce our guest speaker for today. This is Mr. Adams, who is a professional social worker, who works with alcoholics in the Portland area. He will speak to you today on the topic of alcoholism. Please do not ask any questions or make comments during the speech. Time has been provided at the end of the period for this purpose. (step \#2 should take about fifteen minutes).

3. Before our question and answer period, I would like to have you complete a final questionnaire. (Give them ten minutes).

4. Question and answer period. 


\section{APPENDIX J}

\section{PRETEST}

Name

last first middle

A number of statements concerning alcohol and its use are listed below. Please indicate your agreement or disagreement with each statement by encircling the word to the left of each statement which best describes your feeling. Make a decision for every statement. Encircle only one word for each statement.

AGREE DISAGREE 1. Alcoholics Anonymous is a wondrous or-ganization.

AGREE DISAGREE 2. The families of alcoholics should encourage them to seek expert treatment for their condition.

AGREE DISAGREE 3. Private treatment facilities should be available to alcoholics.

AGREE DISAGREE 4. Treatment of alcoholism should be a specialty within the medical profession.

AGREE DISAGREE 5. Tremendous research programs are needed in the area of alcoholism.

AGREE DISAGREE 6. Grants should be readily available to any professional person for research in the area of alcoholism.

AGREE DISAGREE 7. Doctors who spend their time treating alcoholics are wasting their time.

AGREE DISAGREE 8. Neither state nor federal funds should be used for the treatment of alcoholism.

AGREE DISAGREF 9. General hospitals should not accept alcoholics for treatment as such.

AGREE DISAGREE 10. If an alcoholic wanted to be cured, he could accomplish the matter himself. 
AGREE DISAGREE 11. Even if alcoholics could be cured by proper treatment, the cost would be unwarranted.

AGREE DISAGREE 32. The physician who attempts to treat an alcoholic is wasting his time.

AGREE DISAGREE 13. Newspapers should be willing to contri-. bute space for publicizing the problem of alcoholism.

AGREE DISAGREE 14. The facts of alcoholism should be extensively taught in every high school in America.

AGREE DISAGREE 15. Popular literature on alcoholism should be available to any citizen who has the interest to write for it.

AGREE DISAGREE 16. Every dollar spent toward educating the public regarding alcoholism is a dollar exceptionally well spent.

AGREE DISAGREE 17. The more extensive efforts to "educate the public" regarding alcoholism probably serves simply to increase alcoholism.

AGREE DISAGREE 18. The facts of alcoholism are generally unknown to the public.

AGREE DISAGREE 19. Public eaucation concerning alcoholism is a waste of: time and money.

AGREE DISAGREE 20. The general public is already sufficiently informed about the facts of alcoholism.

AGREE DISAGREE 21. Publicity concerning the problem of alcoholism simply adds to the confusion already rampant in the public mina.

AGREE DISAGREE 22. The public has heard enough about alcoholism.

AGREE DISAGREE 23. Only such professional persons as physicjans, social workers, and the like, should receive extensive information concerning alcoholism.

AGREE DISAGREE 24. More interest in the problem of alcoholism should be aroused among the general public. 
AGREE DISAGREE 25. Legal control of alcohol should be on a purely local option basis.

AGREE DISAGRLE 26. Control of alcoholic beverages should be limited to that necessary to prevent drunkenness and evils of excess.

AGREE DISAGREE 27. The present system of county option regarding the sale of alcohol is the most practical and desirable one available.

AGREE DISAGREE 28. State liquor stores should be conveniently accessible to any citizen within the state.

AGREE DISAGREE 29. There should be no legal restrictions on the sale and distribution of alcoholic beverages.

AGREE DISAGREE 30. Those who disagree with the concept of prohibition should feel free to drink even in "dry" areas.

AGREE DISAGREE 31. Liquor and groceries should be taxed proportionately.

AGREE DISAGREE 32. The govermment should have no right to control in any way the accessibility of alcoholic beverages to adult citizens.

AGREE DISAGREE 33. The sale of alcoholic beverages should be more closely supervised and controlled by the government.

AGREE DISAGREE 34. Closer supervision of the sale of alcoholic beverages might well result in less crime, particularly among juveniles.

AGREE DISAGREE 35. Alcoholic beverages should be sold on sundays and holidays.

AGREE DISAGREE 36. The most important goal in alcohol eaucation is to suppress drinking behavior.

AGREE DISAGREE 37. A person who has had the equivalent of one highball should not be allowed to arive an automobile.

AGREE DISAGREE 38. Despite the fact that many millions do use alcoholic beverages, their use is degrading. 
AGREE DISAGREE 39. An individual with no emotional problem has no need for alcohol.

AGREE DISAGREE 40. The "social drinker" is probably basically disturbed emotionally.

AGREE DISAGREE 41. Alcoholic beverages are harmless when used in moderation.

AGREE DISAGREE 42. The use of alcohol is a custom which should be abandoned by society.

AGREE DISAGREE 43. It is all right for women to engage in moderate social drinking.

AGREE DISAGREE 44. Drinking of alcoholic beverages should be classed with the iliegal use of dope.

AGREE DISAGREE 45 . The habit of a before-dinner cocktail is neither beneficial nor harmful.

AGREE DISAGREE 46. Social drinking is all right if, and only if, it is done with moderation.

AGREE DISAGREE 47. One should drink if he enjoys the taste of alcoholic beverages.

AGREE DISAGREE 48. Drinking on some social occasions should be done if it helps the inaividual to fit in with others.

AGREE DISAGREE 49. The alcoholic is basically an insecure person.

AGREE DISAGREE 50. Alcoholism is the direct result of a sick and decadent society.

AGREE DISAGREE 51. Conditions within the individual as well as external to the individual contribute to the development of alcoholism.

AGREE DISAGREE 52. No one should presume to criticize the alcoholic without knowing why he drinks.

AGREE DISAGREE 53. Alcoholism should be treated as a misdemeanor.

AGREE DISAGREE 54. In combating alcoholism as a disease, the effort should be as great as the effort expended in combating any other disease. 
AGREE DISAGREE 55. Only a person who is basically quite malicious could become alcoholic.

AGREE DISAGREE 56. The alcoholic has no one to blame for his troubles but himself.

AGREE DISAGREE 57. Alcoholism begins as the sin of drinking and ends as a sinful habit.

AGREE DISAGREE 58. Alcoholism should be treated as a felony.

AGREE DISAGREE 59. The alcoholic suffers from a severe illness and needs treatment to a much greater degree than the usual medical complaints.

AGREE DISAGREE 60. Al] alcoholjcs are human wrecks found in dives. 
SPEECH GIVEN BY ACTOR IN EXPERIMENTAL CONDITIONS " THE DETRIMENTAL EFEECTS OF ALCOHOL"

Alcohol in any quantity produces a depressing, not a stimulating, action on the central nervous system. When alcohol is ingested and enters the blood stream, the functions of the forebrain are affected first. Judgement is generally impaired, caution is reduced, self-control is lessened, reason is blunted, will power and attention are depressed, the special senses are dulled, and inhibitions begin to be removed.

Small amounts of alcohol do not interfere with digestion, they may even promote it; large amounts slow or stop it. Alcohol is popularly believed to be a respiratory and circulatory stimulant, but this is not true. In addition, statistics show a higher death rate among persons who use alcohol excessively.

The alcoholic, interested only in a life with alcohol, usually follows a pattern of daily living which weakens the disease-resisting power of the body. Statistics show that chronic alcoholics have a higher mortality from pneumonia than moderate drinkers or abstainers and acquire the infection more frequently.

Alcohol has none of the vitamins and minerals and proteins the body needs. An excessive drinker usually neglects food, deriving up to $70 \%$ of his needed calories from alcohol, and is apt to be more interested in arinking than eating. 
The excessive drinker may develop diseases steming from a lack of vitamins. There is no scientific evidence at present to verify that physical tolerance is built up for alcohol. For both regular drinkers and non-drinkers, when the alcohol concentration in the blood reaches a certain point, unconsciousness follows.

Children who grow up in alcoholic families inevitably learn different attitudes toward life and alcohol than do children in normal homes. If more of thern become alcoholics than do people in general, this is due to their experiences and not to heredity. A person from an alcoholic family probably runs a greater risk of alcoholism if he drinks.

The anesthetic effect of alcohol in those portions of the brain which control behavior causes the drinker to become less aware of the need for control, and less conscious of the forces which assist in imposing those controls. Under the influence of alcohol, the individual may becone more primitive in behavior as the basic impulses are released from the acquired controls. The general effect is characterized by a regression from naturity to immaturity and from civilized to uncivilized behavior.

The various stages of intoxication are determined by the increasing concentration of alcohol in the blood. The degree to which normal perfomances are impaired is in direct proportion to the stage of intoxication. One of the early signs of intoxication is when the drinker, because of the effect of alcohol, is unable to recognize his anti- 
social behavior. Loud, boisterous conduct exemplifies such a person. In the second stage, the sense of perception is dulled and the field of observation is narrowed. Clumsiness takes the place of precision due to weak muscular coordination and results in mishaps and loss of efficiency. In the thixd stage, the control of locomotion and muscular movements is seriously disturbed and the ordinary symptoms of drunkenness are manifested. Finally, in the fourth and last stage, the results are stupor, unconsciousness, and coma.

Social pressures often cause social arinking. Having friends, being liked and accepted by the group is important to everyone, young and old, and often one is made to feel that he must drink to be a good sport or to keep from offending someone.

In summary, it would appear that many people who try to resolve their thoughts and actions on the subject are deluged with all sorts of fallacious naterials and ideas. The following factual statements should help clear up misunderstand-ings in this area:

1. Alcohol enters the blood stream at a rapid rate and acts upon the brain and central nervous system, slowing down the reaction time, perception and reflexes.

2. Alcohol is an anesthetic which provides temporary, quick relief from many painful physical and psychological conditions by dulling perception. The release of tensions due to anxiety is chiefly through the anesthetic action of alcohol on higher centers of the brain. 
3. Small amounts of alcohol may increase appetite by increasing the flow of saliva and gastric juices. In large quantities, alcohol interfers with or stops digestion.

4. Alcohol provides calories, but it delivers no vitamins, minerals or proteins and may impede their absorption.

5. Alcohol does not increase efficiency or ability to perform mental or physical work of any sort.

6. Alcohol does not act as a stimulant, although, by reducing inhibitions or consciousness of fatigue, it seems to stimulate.

7. Alcohol has not been proven to be a direct for specific) cause of peptic ulcer, though it can aggravate this condition.

8. Alcohol does not cure colds. It may promote perspiration and reljef from discomfort which may aid recovery if the patient stays in bed. Heavy drinkers, whose resistance is lowered by poor habits generally, are more susceptible to death from pneumonia than others.

9. Alcohol does not differ in its effect according to the form of beverage in which it is incorporated; the chief factor is the amount of alcohol present in different beverages. 
APPENDIX I,

POSTrEST

Name

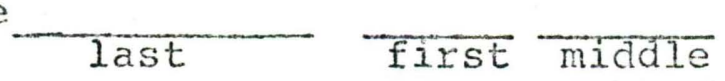

A number of statements concerning alcohol and its use are listed below. Please indicate your agreement or disagreement with each statement by encircling the word, to the left of each statement, which best describes your feeling. Make a decision for every statement. Encircle only one word for each statement.

AGREE DISAGREE 1. A national organization simjlar to the Cancer Society should be established and supported for treatment of alcohol-ism.

AGREE DISAGREE 2. Oregon should establish more treatment facilities for alcoholics.

AGREE DISAGREE 3. For successful treatment of alcoholism both medical and psychological techniques should be used.

AGREE DISAGREE 4. The most successful treatment of alcoholism attempts to help the individual regain his will power.

AGREE DISAGREE 5. The Division of Alcoholism is a waste of the taxpayer's money.

AGREE DISAGREE 6. Money spent for research on alcoholism would be better spent on other things.

AGREE DISAGREE 7. Individual psychological counseling is the most effective way for treating the alcoholic.

AGREE DISAGREE 8. The Division for Alcoholism is an organization of vital importance to all.

AGREE DISAGREE 9. Science has no real hope of finding a cure for alcoholism. 
AGREE DISAGREE 10. The wholesale treatment of alcoholics is impractical.

AGREE DISAGREE 11. It is impractical to offer treatment to all alcoholics who might want it.

AGREE DISAGREE 12. The treatinent of alcoholism should be uncertaken oniy by the individual's own farily and friends.

AGREE DISAGREE 13. Public education is an integral part of the treatment of alcoholism as a social problem.

AGREE DISAGREE 14. Alcoholism should be as widely and as freely discussed among the general public as cancer or heart disease.

AGREE DISAGREE 15. Cooperative community effort is needed to provide the facts about alcohol.

AGREE DISAGREE 16. Public education programs concerning alcoholism are useless.

AGREE DISAGREE 1.7. It is impractical to attempt to educate the public concerning the facts of alcoholism.

AGREE DISAGREE 18. There is no real need for a specific educational program on alcoholism in Oregon.

AGREE DISAGREE 19. The public could do with less emphasis on the problem of alcoholism.

AGREE DISAGREE 20. Literature concerning alcoholism should not be freely available to the general. public.

AGREE DISAGREE 21. More information should be available to the general public regarding alcoholism.

AGREE DISAGREE 22. Infornation concerning alcoholism should be restricted to those directly involved.

AGREE DISAGREE 23. The public deserves to be kept informed regarding the topic of alcoholism.

AGREE DISAGREE 24. The Division of Alcoholism should distribute more information among the general public. 
AGREE DISAGREE 25. If the federal government refuses to enforce prohibition, it is up to the individual states.

AGREE DISAGREE 26. Manufacture of alcohol should be restricted even though we have an excess of cereal grains available.

AGREE DISAGREE 27. The law has no more right to restrict the sale of alcohol than it does the sale of bread.

AGREE DISAGREE 28. The present system involving state liquor stores is quite satisfactory.

AGREE DISAGREE 29. The heavy tax on liquor is unfair.

AGREE DISAGREE 30. Alcoholic beverages should be as freeIy available as cigarettes.

AGREE DISAGREE 31. Alcohol should be freely available to anyone over 18 years of age.

AGRJE DISAGREE 32. Any business should be able to acquire a liquor license at nominal cost.

AGREE DISAGREE 33. The costs of liquor licenses should be decreased.

AGREE DISAGREE 34. Alcohol is much too freely avajlable to adolescents.

AGREE DISAGREE 35. The cost of liquor licenses should be increased.

AGREE DISAGREE 36. Enforcement of liquor Iicenses should be increased.

AGREE DISAGREE 37. Drinking is OK as a business courtesy.

AGREE DISAGREE 38. Drinking is, itself, as bad as any improper behavior which may result.

AGREE DISAGREE 39. Public drinking is more to be frowned upon than drinking in the home.

AGREE DISAGREE 40. Taking a cocktail before dinner is the first step toward alcoholism.

AGREE DISAGREE 41. Parents who arink in front of their children would do better to flog them. 
AGREE DISAGREE 42. SOcial drinking adds to our relaxation and pleasure.

AGREE DISAGREE 43. Moderate drinking shoula be regarded as neither good nor evil.

AGREE DISAGREE 44 . Whether or not a person drinks has nothing to do with his will power or emotional health.

AGREE DISAGREE 45. Even moderate drinking eventually produces harmful consequences.

AGREE DISAGREE 46. Aicohol in moderatjon has no real effect upon a person's personality.

AGREE DISAGREE 47. A few drinks are quite relaxing after a hard day's work.

AGREE DISAGREE 43. A job applicant who drinks at all is probably a bad prospect.

AGREE DISAGREE 49. The alcoholic deserves the same consideration as any other sick person.

AGREE DISAGREE 50. The alcoholic has only himself to blame for his problems.

AGREE DISAGREE 51. The alcoholic is simply a sick person who needs care and sympathy.

AGREE DISAGREE 52. Alcoholism can only exist in a general atmosphere of greed.

AGREE DISAGREE 53. The alcoholic is more to be envied than pitied.

AGREE DISAGREE 54. Alcoholism is a disease and should be treated as such.

AGREE DISAGREE 55. Alcoholism is a condition which is best ignored.

AGREE DISAGREE 56. The alcoholic basically enjoys the attention which he usually gets.

AGREE DISAGREE, 57. Only an exceedingly selfish and unthinking person becomes an alcoholic.

AGREE DISAGREE 58. Alcoholism is a deliberate crime against society. 
AGREE DISAGREE 59. Most alcoholics would resent an offer of free treatment for their condition.

AGREE DISAGREE 60. The alcoholjc should be treated as the criminal which he is. 


\section{PERSONAL INFORMATION}

Total $\mathrm{N}=168$

\begin{tabular}{|c|c|c|c|}
\hline Years & 14 & 15 & 16 \\
\hline Number & 21. & 113 & 22 \\
\hline Percent & 13.5 & 72.4 & 14.1 \\
\hline \multicolumn{4}{|c|}{$N=156$} \\
\hline \multicolumn{4}{|l|}{ SEX } \\
\hline Gender & Male & & Female \\
\hline Number & 85 & & 83 \\
\hline Percent & 51. & & 49.0 \\
\hline
\end{tabular}

NUMBER OF ORGANIZATIONS ATPENDED

Number of

organizations

01

2

3

4

\begin{tabular}{lllllll}
$\begin{array}{l}\text { Number of } \\
\text { Responses }\end{array}$ & 55 & 35 & 26 & 24 & 23 \\
\hline Percent & 33.7 & 21.5 & 16.0 & 14.7 & 14.1 \\
\hline
\end{tabular}

$N=163$ 
TYPES OF ORGANIZATIONS

Type Social Professional Hobby Religious

\begin{tabular}{lccccc}
\hline Response & 66 & 2 & 43 & 35 & \\
\hline Active In & 34 & 1 & 15 & 11 & \\
\hline TYPES OF ORGANIZATIONS & continued & & \\
\hline Type & SOcial & Activity & Service & Political & Other \\
\hline Response & 10 & 22 & 25 & 0 \\
\hline Active In & 3 & 9 & 3 & 0 \\
\hline
\end{tabular}

RELIGIOUS PREEERENCE

Religion Protestant Catholic Jewish other

\begin{tabular}{lllll}
\hline Num. of resp. & 99 & 31 & 3 & 26 \\
\hline Percent & 62.3 & 19.5 & 1.9 & 16.4 \\
\hline
\end{tabular}

$N=159$

ATTENDANCE AT CHURCH

Attendance Regular Occasional Seldom Never

\begin{tabular}{lllll}
\hline Frequency & 67 & 28 & 39 & 33 \\
\hline Percent & 40.1 & 16.8 & 23.4 & 19.8 \\
\hline
\end{tabular}


TYPES OF OCCUPATIONS PREPARIING FOR

\begin{tabular}{lcccc} 
Type & White Collar & Blue Collar & Prof. & Undecided \\
\hline Num. resp. & 71 & 16 & 37 & 21 \\
\hline Percent & 49.0 & 11.0 & 25.5 & 14.5 \\
\hline & $N=145$
\end{tabular}

IMMEDIATE PLANS AFTER HIGH SCHOOI

Plans Work Tech./Voc. School College Military oth.

\begin{tabular}{llllll}
\hline Number & 29 & 33 & 90 & 20 & 7 \\
\hline Percent & 17.2 & 13.6 & 53.3 & 11.8 & 4.1. \\
\hline
\end{tabular}

GRADES EARNED

\begin{tabular}{lccc}
\hline Grades & A-B & C & $D-F$ \\
\hline Number & 69 & 95 & 4 \\
\hline Percent & 41.1 & 56.6 & 2.4 \\
\hline
\end{tabular}

$N=168$ 


\begin{tabular}{lcc} 
ATTENDANCE & OF & SCHDOL OUTSIDE SALFM AREA \\
\hline & Yes & No \\
\hline Number & 87 & 79 \\
\hline Percent & 52.4 & 47.6 \\
\hline & $N=166$
\end{tabular}

\begin{tabular}{lccccc} 
AREA OF BIRTH & & & \\
\hline Area & Salem & Western States Midwest & Eastern & Foreign \\
\hline Number & 68 & 75 & 9 & 6 & 2 \\
\hline Percent & 42.5 & 46.9 & 5.6 & 3.8 & 1.3
\end{tabular}

$$
N=160
$$

PARENTS AGE

\begin{tabular}{lccccccc}
\hline Age & $30-34$ & $35-39$ & $40-44$ & $45-49$ & $50-54$ & + \\
\hline Father & 7 & 31 & 38 & 30 & 20 & 14 \\
\hline \% Response & 5.0 & 22.1 & 27.1 & 21.4 & 14.3 & 10.0 \\
\hline Mother & 17 & 40 & 39 & 39 & 13 & 6 \\
\hline 8 Response 11.0 & 26.0 & 25.3 & 25.3 & 8.4 & 3.9 \\
\hline
\end{tabular}


SIBLINGS

Yes No

\begin{tabular}{lcc}
\hline Number & 162 & 5 \\
\hline Percent & 97.0 & 3.0 \\
\hline & $N=167$
\end{tabular}

PARENTS EDUCATION

\begin{tabular}{lcccc}
\hline Years & $0-8$ & $9-12$ & $13-16$ & $17+$ \\
\hline Father & 21 & 74 & 38 & 10 \\
\hline \% Response 14.7 & 51.8 & 26.6 & 7.0 \\
\hline Mother & 11 & 95 & 37 & 3 \\
\hline Response & 7.5 & 65.1 & 25.3 & 2.1 \\
\hline
\end{tabular}

POLITICAL PREFERENCE

\begin{tabular}{lccc}
\hline Party & Democrat & Republican & Other \\
\hline Father & 69 & 56 & 8 \\
\hline \% Response & 51.9 & 42.1 & 6.0 \\
\hline Mother & 62 & 66 & 10 \\
\hline Response & 45.0 & 47.8 & 7.2 \\
\hline
\end{tabular}


FATHERS INCONE

\begin{tabular}{lcccc}
\hline Income & $\$ 0-\$ 3,999$ & $\$ 4,000-7,999$ & $\$ 8,000-11,999$ & $\$ 12,000+$ \\
\hline Number & 8 & 40 & 45 & 23 \\
\hline Percent & 5.9 & 34.5 & 38.8 & 19.8 \\
\hline
\end{tabular}

$N=11.6$

FAMILY MOVES

\begin{tabular}{lcccc}
\hline Moves & 0 & 1 & 2 & $3+$ \\
\hline City to city & 114 & 19 & 11 & 15 \\
\hline Percent & 71.7 & 1.2 .0 & 7.0 & 9.4 \\
\hline Within city & 108 & 22 & 12 & 22 \\
\hline Percent & 65.9 & 13.4 & 7.3 & 13.4 \\
\hline & & $\begin{array}{l}N=159 \\
N=164\end{array}$ & $\begin{array}{l}\text { (City to city) } \\
\text { (With city) }\end{array}$
\end{tabular}




\section{THE STUDENT POPULATYON}

As the experiment was conducted on two different days, the experimenters expected some attrition of students aue to sickness and other normal causes of absences. The experimenters were also prepared for an addition of students on the second experimental day who had not been present at school on the first experimental day. In each of the questionnaires that the students were asked to fill out, space was provided for either thejr full name or their initials. Thus, it was possible to accurately match forms and to cross check from one form to the next. As previously mentioned, the students were told that the names on the form would be used only for matching purposes, and would not in any way affect their grades.

A total of 169 knowledge questionnaires were collected, but the personal information sheet administered on the same day reflected a drop of one student. On the second day of the experiment, only the posttest was administered to all of the students and the total number collected was 152. Each student's alcohol knowledge questionnaire from the first and second experimental days was then matched so that comparisons could be made concerning attitude change toward alcohol usage. This, plus the fact that several students had to be eliminated because they failed to properly identify their questionnaires with either their initials or their entire names, left a total of 140 students for consideration in the final tabu- 
lation of the data. The breakdown into experimental conditions is illustrated in Table I of Chapter III.

The unequal number of students in each condition reflects, first, the size difference of the two periods. Third period had a total of 73 students; fourth period had a total of 67 students that were included in the final experimental condition. The other reason for the different number of students in each experimental condition is that the students were assigned to conditions based on the scores they received on the knowledge questionnaires which were administered on the first day of the experiment. Thus, the experimenters had no control over the attrition of students and shifts made due to student absences.

The scores obtained from the alcohol knowledge questionnaires were used to assign students to the six various experimental conditions. The spread of the scores (which were based on the number of incorrect answers out of a total of 87) ranged from 49 to 23 incorrect responses. As the exper imenters were unable to shift students from one school period to the next, we were forced to assign the students to classes within each period. This was accomplished by randomly assigning all students who received a score of 49 to each of the three conditions; then all who received a score of 48 were randomly assigned to the classes and so on through the score of 23. This method was used for both periods. When there were only two people having a single score, one student was 
included who had the next lower score. For example, if only two students received scores of 49 , then another student was included who had received a score of 48; then the three were randomly assigned to each of the three experimental conditions. 


\section{IMPRESSIONS}

The first contact the students had with the experiment was september 15, 1969. They were in their regularly scheduled classroom settings. The teachers were asked to distribute the material and to keep their answers to any questions to a minimum. The three teachers indicated that the students followed directions; accepted the explanations given, and completed the questionaires.

Following the experiment conducted on september 22, 1969, impressions were gathered from the various people involved as to the effectiveness of the presentation, validity of the actor, impact of the presentation, and any other free flowing comments that were expresscd or witnessed during and after the experiment.

\section{Impressions of the Actor}

The actor was asked whether he had felt any difference in the responses he received from the students when he was introduced as the doctor or the socjal worker. He said that he picked up no difference in the responses from the students to hin in the different roles. "Each class appeared to be paying attention to what was saja and I could not tell any difference in the attention span or depth of concentration to what was being said. Fach class appeared to be paying attention pretty well." The actor was asked whether he 
felt any difference, himself, when he was introduced in the different roles and he replied: "No, I felt just the same in either role and attempted to present the material the same." He was asked if he felt there was any difference in the nanner of presentation; that is, the way and ease with which the material was read between the first and last presentations. He indicated that he had read the material thoroughly before presenting it and felt that he had maintained the same level of speed and tone inflection, and number of times he referred to the naterial while presenting it was approximateIy the same. One of the experimenters timed the four presentations and found that they were all within two minutes of each other. The variation was attributed to a difference in readiness of the teachers to introduce the actor. Also, the actor entered the classroom when he assumed that the pretesting was completed and reported that the waiting was due to the collection of the tests.

The actor was asked if he received any verbal or nonverbal feedback from any of the students. He indicated that the time element was such that no time was available for verbal feedback; his impression was that he received no nonverbal feedback. "The students listened, and the speech was short enough so that they did not start moving around in their chairs." The general impression of the actor is that each class received the same in method of presentation, and the responses to the presentation were very similar in all 
of the experimental conditions.

\section{Impressions of the reachers}

Each teacher was fixst asked to call roll and then to identify those students who were to change classes. All. three teachers indicated they were asked by the students why they were being moved, but they did not provide any explanation beyond the fact there was going to be a change in the classes for that day only. Since the time element was stressed to the teachers before the experiment itself commenced, they were aware of its importance and did not pause to answer questions until after the final test had been conpleted and collected.

The teachers were interviewed concerning theix impressions of the presentation, itself. All three had the same general comments as did the actor concerning the verbal and non-verbal responses from the students. They indicated that several questions arose after the actor had left the room. Non-verbal communication was observed in that the student paid close attention to the presenter and shifted little in their seats. The teachers were questioned closeIy regarding side glances, whispered comments to fellow students, or any other form of distractive commication. Each teacher observed side glances which were between friends but did not see anything distracting or otherwise significant in relation to the material being presented. The two teachers 
having the control group conditions were asked to comment on how the study time was utilized by the students; their instructions were to provide a study period. The teachers felt that, for the most part, the students were cooperative. During the tests, some of the students had questions about the meaning of certain words in the tests. The teachers responded only by explaining or defining the word with a minimum of elaboration. Some of the words that required an interpretation were: "dry areas," "Alcoholics Anonymous," "misdemeanor," and "on the wagon."

The bulk of questions from the students came after the last test had been completed, handed in, and before one of the experimenters corld come into the room to explain the entire sequence. Typically, questions arose in the areas of "the effects of alcohol." Many students wanted to know what various types of drinks would do to them and how much alcohol would be required to get a person drunk; for example, "Can I get drunk on three beers?" The teachers attempted to answer the questions as best they could in relation to the effects of alcohol. When the experimenter revealed the true identity of the actor, many students were surprised and expressed that they had accepted the person as introduced. Some responded with "Are you really, who you say you are?", "Man, have we been fooled!", and "Who can we believe now?" These responses wexe in accord with the experimenter's expectations as they had recently entered a new school and 
were usually willing to participate in new experiences. The teachers reported later that the students asked for reassurance from them as to what had actually happened, what they had been a part of and, who, exactly, was the actor. The subject of alcohol was of sufficient interest to them that they returned to that topic as soon as they had been reassured.

\section{Impressions of the School Principal}

The experimenters had considerable contact with the school principal prior to and during the planning stages of the experiment. He was questioned concerning any feedback about the experiment that he received from the students or the teachers. He indicated that the only feedback he received was from the teachers concerning the smoothness with which the experiment had been conducted. The principal also indicated that the teachers were pleased with the response they received from the students and were confident that they, as teachers, had done as instructed. The principal received no feedback from the students.

\section{Impressions of the Experimenters}

One of the experimenters indicated that she was of the impression that the actor felt and functioned equally confortably in both roles. Having had the opportunity to observe him assuming the role of the physician and the role of the social worker from outside the classroom, she was able to evaluate the presentation in a way similar to that of the 
students. This experimenter also felt that the actor spoke slowly and distinctly; his voice was steady and natural. Eye contact with the students was "natural," in that he had looked down at the written information occasionally. Thus, he did not convey the impression that he had a memorized speech or that it did not really contain his own convictions concerning the subject of alcohol usage. He did not appear to be merely "parroting" information with which he was actually not too famjiliar. Finally, this experimenter felt that in both roles, the actor functioned in the same consistent manner, and in both situations, the students listened quietly and attentively.

One of the experimenters observed and had the feeling that the teachers vere cooperative and anxious to help. The teachers appeared to be interested in the experiment and wanted feedback concerning the results and findings of the experiment when they were tabulated. The teachers appeared comfortable with the experimental situation and expressed no reservations about introducing and taking responsibility for the actor. They offered to help with the mechanics of the experiment in any way that they could. In summary, the following attitudes were expressed by the teachers:

1) They were more than happy to help as they had been through this themselves.

2) This is information of value and related to student interest. 
3) It is information that all students should have; many are not given any information or training at home.

4) They (the students) can learn about biology any day of the week.

The other experimenter explained the experimental situation to the students and answered pertinent questions following the final presentation. At the end of the third period classes, he indicated to the students that they had been asked to answer the questions to determine how much they knew about alcohol usage and abusage. They were told that they would receive a more complete account of the experience they had been a part of on the following day; they were asked not to talk about what they had just experienced. Again, from all indications, the students responded as requested and did not talk about the test; this was supported by the fact that the fourth period classes appearea to be surprised to learn that the actor was actually neither a social worker nor a physician.

This experimenter talked to the fourth period classes on the second day of the experiment and to the third period classes on the following day. Upon explaining the full and true nature of the study, the students registered a surprise. Typical comments were that they had not known who the actor was and had accepted him as introduced. The content of the material was discussed and the questions centered around "the effects of alcohol usage." Feedback and impressions 
such as these indicate that the students did listen to the content of the material and were attentive to the communicator while he was delivering the presentation. Some students were able to remember some of the information that had been presented in the speech as a further indication that they were listening to the content.

\section{Summary}

The concensus of all who were involved in the experiment was that:

1) Verbal and non-verbal feedback indicated that the students did listen to the presented material.

2) The students accepted the actor as introduced and had no reason to doubt his role at the time of the presentation.

3) Contamination from students in one class period revealing information to the next was minimal.

4) Some connection was macle between the material in the first and second days but with no significant effect.

5) The students accepted the mechanics of the experiment and complied with the instructions. 